\title{
Triphenyltin(IV) benzoates with diazenyl/ imino scaffold exhibiting remarkable apoptosis mediated by reactive oxygen species
}

Tushar S. Basu Baul, ${ }^{* a}$ Dhrubajyoti Dutta, ${ }^{a}$ Andrew Duthie, ${ }^{b}$ Ritika Prasad, ${ }^{\mathrm{c}}$ Nishant Kumar Rana, ${ }^{\mathrm{c}}$ Biplob Koch, ${ }^{* \mathrm{c}}$ and Edward R. T. Tiekink*d

${ }^{a}$ Centre for Advanced Studies in Chemistry, North-Eastern Hill University, NEHU Permanent Campus, Umshing, Shillong 793 022, India

${ }^{b}$ School of Life \& Environmental Science, Deakin University, Geelong, Victoria 3217, Australia

${ }^{c}$ Genotoxicology and Cancer Biology Lab, Department of Zoology, Banaras Hindu University, Varanasi, India

${ }^{d}$ Research Centre for Crystalline Materials, Faculty of Science and Technology, Sunway University, 47500 Bandar Sunway, Selangor Darul Ehsan, Malaysia

*Corresponding authors.

E-mail addresses: basubaul@nehu.ac.in, basubaulchem@gmail.com (T. S. Basu Baul), biplob@bhu.ac.in, kochbiplob@gmail.com (B. Koch), edwardt@sunway.edu.my (E. R. T. Tiekink) 


\section{ABSTRACT}

The cytotoxic potency of a series of triphenyltin(IV) compounds of general composition $\left[\mathrm{Ph}_{3} \mathrm{Sn}\left(\mathrm{L}^{\mathrm{n}}\right)\right]($ 1-6) has been probed in vitro employing MDAMB-231 (human breast cancer) and HeLa (human cervical cancer) cell lines, where $\mathrm{L}^{\mathrm{n}}=\mathrm{L}^{1-3}$; isomeric 2/3/4-\{(E)-2-[4-(dimethylamino)phenyl]diazenyl $\}$ benzoates and $\mathrm{L}^{4-6}$ are their corresponding isoelectronic imino analogues 2/3/4-[(E)- $\{[4-$ (dimethylamino)phenyl]methylidene\}amino]benzoates. Compounds 1-6 have been characterized by elemental analysis and their spectroscopic properties were studied using IR and NMR $\left({ }^{1} \mathrm{H},{ }^{13} \mathrm{C},{ }^{119} \mathrm{Sn}\right)$ techniques. The molecular structures of a pro-ligand 2-[(E)-\{[4(dimethylamino)phenyl]methylidene amino]benzoic acid $\left(\mathrm{HL}^{4}\right)$ and two representative molecules, $\mathrm{Ph}_{3} \operatorname{Sn}\left(\mathrm{L}^{2}\right) 2$ and $\mathrm{Ph}_{3} \mathrm{Sn}\left(\mathrm{L}^{5}\right) \mathbf{5}$, have been determined by X-ray crystallography. Structural analyses of 2 and 5 revealed distorted tetrahedral geometries within $\mathrm{C}_{3} \mathrm{O}$ donor sets owing to monodentate modes of coordination of the respective carboxylate ligands, close intramolecular $\mathrm{Sn}$... O(carbonyl) interactions notwithstanding. Cytotoxic studies in vitro in MDAMB-231 and HeLa cell lines revealed high activity, in sub-micromolar range, for all investigated compounds. Among these, $\mathbf{1}$ and $\mathbf{3}$ exhibited potent cytotoxicity most effectively towards MDAMB-231 cells with a $\mathrm{IC}_{50}$ value of 1.19 and $1.44 \mu \mathrm{M}$, respectively, whereas 5 showed remarkable activity towards $\mathrm{HeLa}$ cells with a $\mathrm{IC}_{50}$ value of $0.88 \mu \mathrm{M}$, yet the series of compounds had minimal cytotoxic effect on normal HEK 293 (human embryonic kidney) cell line. The underlying investigation suggested that the compounds exert potent antitumor effect by elevating intracellular reactive oxygen species generation and cause delay in cell cycle by inhibiting cells at $\mathrm{G}_{2} / \mathrm{M}$ phase. The results presented herein suggest further development of this class of triphenyltin(IV) compounds-based drugs as potential anti-cancer therapies should be pursued.

Keywords: Triphenyltin(IV) compounds; modular ligands; Crystal structures; MDAMB-231 and HeLa cells; cytotoxicity; reactive oxygen species 


\section{Introduction}

Cisplatin, cis-diammine-dichloroplatinum(II) (CDDP), a square planar Pt(II) complex remains in the frontline of inorganic chemotherapeutic agents for the treatment for cancer [1-4]. The clinical effectiveness of CDDP is limited by considerable side effects and the emergence of drug resistance. Consequently, a number of second- and third-generation CDDP analogues including carboplatin, oxaliplatin, nedaplatin, heptaplatin, lobaplatin and satraplatin were developed for use in the treatment of various cancers. These advances have spurred a surge of investigations to identify new inorganic agents (non-platinum metals) for use in chemotherapy with improved specificity and decreased toxic side effects. Accordingly, non-platinum metallodrugs such as $\mathrm{Ru}, \mathrm{Cu}, \mathrm{Au}, \mathrm{Pd}, \mathrm{Fe}, \mathrm{Co}, \mathrm{Ti}, \mathrm{Ga}, \mathrm{Ni}, \mathrm{Rh}, \mathrm{Ir}, \mathrm{Sn}, \mathrm{Os}, \mathrm{Zn}, \mathrm{V}$, $\mathrm{Ag}, \mathrm{Re}, \mathrm{Mo}$ and lanthanide complexes have emerged and shown to exhibit comparable or better cytotoxic properties accompanied by different specificities towards cancer cells, and by a more favourable pharmacological and toxicological profiles [5,6]. Review articles describing the application of transition metal complexes as anti-cancer agents are available in the literatures [7-23].

On the other hand, organotin(IV) compounds have displayed diverse medicinal applications such as anti-viral, anti-microbial, anti-parasitic, anti-hypertensive, anti-hyperbilirubinemia and anti-cancer activities, apart from their standard uses as biocides, catalyzers and stabilizers [24-29]. Compared to standard drugs, the majority of organotin(IV) carboxylates discussed in the literature have shown superior anticancer activity against various cell lines. Additionally, some of them have demonstrated distinct anticancer activity even against CDDP-resistive cancer cells. Organotin(IV) compounds with pronounced medicinal properties also exhibit drawbacks such as reproductive toxicity, neurotoxicity and other toxic effects apart from poor water solubility; however, these can be circumvented by a rational design of the structures of the compounds but the vital point still remains the activity. In practice, organotin(IV) compounds are dissolved in DMSO and diluted with test medium prior to in vitro testing. Nevertheless, the limited solubility needs to be further enhanced in a way comparable to CDDP, which also shows limited water solubility. It is therefore important to find more effective and safer organotin(IV) compounds for therapeutic use by designing and synthesizing new compounds and to find suitable means of their delivery to the bio-targets. In this pursuit, recently a novel biocompatible strategy of drug delivery employing nanostructured silica-based material loaded with triphenyltin(IV) compound was used. This resulted in increase in efficacy of the drug and the pattern of action leads to the non-aggressive suppression of melanoma tumor growth with non-recognizable toxicity toward normal tissue [30]. While the potency of a drug is a very important consideration, drug selectivity towards cancer cells is key to ensuring both safety and effectiveness [31]. Additionally, the mechanism of action of organotin(IV) compounds in achieving cell death remains uncertain, and hence additional work is essential to identify the actual apoptotic or 
necrotic pathways.

In view of the above, careful functionalization of a series of organotin compounds was undertaken. In this endeavour, six pro-ligands (i) isomeric 2-, 3- and 4-\{(E)-2-[4(dimethylamino)phenyl]diazenyl benzoic acids and their isoelectronic imino counterparts, i.e. (ii) 2-, 3and 4-[(E)-\{[4-(dimethylamino)phenyl]methylidene $\}$ amino $]$ benzoic acid, have been designed and their triphenyltin(IV) esters prepared (Fig. 1). In the first three pro-ligands $\left(\mathrm{HL}^{1-3}\right)$, the aryl moieties are linked by a diazenyl skeleton while in the others $\left(\mathrm{HL}^{4-6}\right)$ by an imino group, substitution patterns which offer flexibility in the molecules. The presence of the carboxylate group is vital for aqueous solubility and results in increased cellular accumulation [32,33]. The incorporation of the triphenyltin(IV) moiety in the molecule offers much higher activities when compared with titanocene derivatives and CDDP [34-36]. Thus, it is expected that the modification of the carboxylate ligands in the current series by incorporating $\mathrm{SnPh}_{3}$ can optimize the cytotoxicity [37,38] while varying the location of the triphenyltin ester can modulate the activity at a specific target. In this context, cytotoxic properties of series of $\left[\mathrm{Ph}_{3} \mathrm{Sn}\left(\mathrm{L}^{\mathrm{n}}\right)\right]$ complexes $\left[\mathrm{L}^{\mathrm{n}}=\right.$ $\mathrm{L}^{1-3}$ (1-3) and $\mathrm{L}^{4-6}$ (4-6)], were determined towards the MDAMB-231 (human breast cancer) and HeLa (human cervical cancer) cell lines. To realize the mechanistic/mode of cell death objective, an additional series of experiments were conducted: (i) the cytotoxic activity was examined by MTT (3-(4,5dimethylthiazol-2-yl)-2,5-diphenyltetrazolium bromide) assay (ii) the ability of the test compounds to generate ROS (reactive oxygen species) in the cells was examined using DCFH-DA (dichlorodihydrofluorescein diacetate) dye (iii) apoptosis or mode of cell death was detected by Hoechst 33342/PI (propidium iodide) and annexin V-PI assay and (iv) cell cycle arrest by the compounds were examined by FACS (fluorescence-activated cell sorting) studies. The biological results indicated that the triphenyltin(IV) compounds show potent cytotoxicity which can be modulated either by varying the positions of the triphenyltin(IV) ester across a series or switching from triphenyltin(IV)- diazobenzoato- to -iminobenzoatoligands. The present studies demonstrated that the triphenyltin(IV) compounds exert their cytotoxic effect by elevating intracellular ROS generation as discussed below.

\section{Insert Fig. 1.}

\section{Experimental}

\subsection{Materials and physical measurements}

$\mathrm{Ph}_{3} \mathrm{SnOH}$ (Aldrich), anthranilic acid (Sigma-Aldrich), 3-aminobenzoic acid, 4-aminobenzoic acid, 4-(dimethylamino)benzaldehyde (SRL) and dimethylaniline (sd fine-chem) were used without further purification. The solvents used in the reactions were of AR grade and were dried using standard 
procedures. Toluene was distilled from sodium. Dulbecco's modified eagle medium (DMEM), fetal bovine serum (FBS) (Cellclone, Genetix Biotech Asia), penicillin $1000 \mathrm{IU}$, streptomycin $10 \mathrm{mg} / \mathrm{mL}$, trypsin, 3-(4, 5-dimethylthiazol-2-yl)-2,5-diphenyltetrazoliumbromide dye (MTT) (Himedia), dimethyl sulphoxide (DMSO), RNAse (GeNie, Merck), 2',7'-dichlorodihydrofluorescein diacetate (DCFH-DA), Hoechst 33342 (Sigma), propidium iodide (PI) (EMD Millipore-Calbiochem), Annexin V Alexa flour 488 conjugate (Life Technologies; Invitrogen Bioservices India Pvt. Ltd.), cytoplatin (Cipla; generic name- cisplatin), Triton X100 and other analytical grade chemicals (Lobachemie) were used.

Melting points were measured using a Büchi melting point apparatus M-560 and are uncorrected. Carbon, hydrogen and nitrogen analyses were performed with a Perkin-Elmer 2400 series II instrument. IR spectra in the range $4000-400 \mathrm{~cm}^{-1}$ were obtained on a Perkin Elmer Spectrum BX series FT-IR spectrophotometer with samples investigated as $\mathrm{KBr}$ discs. Absorption measurements of compounds 1-6 were carried out on a Perkin-Elmer Lambda25 spectrophotometer at ambient temperature in benzene and DMSO solutions. ${ }^{1} \mathrm{H}$ and ${ }^{13} \mathrm{C}\left\{{ }^{1} \mathrm{H}\right\}$ NMR spectra, measured at 400.13 and $100.62 \mathrm{MHz}$ respectively, were recorded on a Bruker AMX 400 spectrometer. ${ }^{119}$ Sn NMR spectra were measured on a Jeol GX 270 spectrometer at $100.75 \mathrm{MHz}$. The ${ }^{1} \mathrm{H},{ }^{13} \mathrm{C}$ and ${ }^{119} \mathrm{Sn}$ chemical shifts were referenced to $\mathrm{Me}_{4} \mathrm{Si}(\delta 0.00 \mathrm{ppm})$, $\mathrm{CDCl}_{3}(\delta 77.00 \mathrm{ppm})$, and $\mathrm{Me}_{4} \mathrm{Sn}(\delta 0.00 \mathrm{ppm})$, respectively. Equipment such as ELISA plate reader, Microscan (MS5608A), inverted fluorescence microscopy (Nikkon E800) and Inverted fluorescent microscope (Evos FL, Life technologies, AMF4300) were used for biological work.

\subsection{Synthesis of pro-ligands}

Pro-ligands 2-\{(E)-2-[4-(dimethylamino)phenyl]diazenyl $\}$ benzoic acid $\quad\left(\mathrm{HL}^{1}\right), \quad 3-\{(E)-2-[4-$ (dimethylamino)phenyl]diazenyl $\}$ benzoic acid $\left(\mathrm{HL}^{2}\right)$ and 4-\{(E)-2-[4-(dimethylamino)phenyl]diazenyl\}benzoic acid $\left(\mathrm{HL}^{3}\right)$ and 2-[(E)-\{[4-(dimethylamino)phenyl]methylidene $\}$ amino $]$ benzoic acid $\left(\mathrm{HL}^{4}\right)$ were prepared by the method described earlier [39] and purities were established from melting point, elemental analysis and ${ }^{1} \mathrm{H}$ NMR spectroscopy prior to use. The synthetic details of the pro-ligands $\mathrm{HL}^{5}$ and $\mathrm{HL}^{6}$, including their characterization and spectroscopic data are described below.

\subsubsection{Synthesis of 3-[(E)-\{[4-(dimethylamino)phenyl] methylidene $\}$ amino $]$ benzoic acid $\left(H L^{5}\right)$}

A similar synthetic procedure to that used for $\mathrm{HL}^{4}$ was used [39] except that anthranilic acid was replaced by 3 -aminobenzoic acid. The crude product was then recrystallized from methanol to give brown powder in $65 \%$ yield. M.p.: $200-202{ }^{\circ} \mathrm{C}$. Anal. calc. for $\mathrm{C}_{16} \mathrm{H}_{16} \mathrm{~N}_{2} \mathrm{O}_{2}: \mathrm{C}, 71.62 ; \mathrm{H}, 6.01 ; \mathrm{N}, 10.44 \%$. Found.

C, $71.60 ; \mathrm{H}, 5.80 ; \mathrm{N}, 10.28 \%$. IR $\left(\mathrm{cm}^{-1}\right): 1682 v(\mathrm{OCO})_{\text {asym. }}{ }^{1} \mathrm{H}-\mathrm{NMR}\left(\mathrm{CDCl}_{3}+\mathrm{DMSO}_{6}\right): \delta_{\mathrm{H}} ; 8.04[\mathrm{~s}, 1 \mathrm{H}$, 
H-15], 7.50-7.30 [m, 2H, H-2 \& H-4], 7.15-7.0 [m, 1H, H-5], 7.13-7.04 [m, 1H, H-5], 6.98-6.75 [m, 2H, H9 \& H-13], 6.50 [d, 1H, H-6], 6.45-6.35 [m, 2H, H-10 \& H-12], 2.85-2.60 [s, 6H, H-14] ppm. Signals for the carboxylic acid were exchanged due to presence of water in the solvent. ${ }^{13} \mathrm{C}-\mathrm{NMR}\left(\mathrm{CDCl}_{3}+\mathrm{DMSO}-\right.$ $\left.d_{6}\right): \delta_{\mathrm{C}} ; 189.5$ [C-1], 160.5 [C-15], 152.3 [C-11], 148.5 [C-7], 131.7 [C-3], 130.4 [C-9 \& C-13], 129.0 [C5], 121.3 [C-8], 118.0 [C-6], 114.6 [C-4], 111.2 [C-10 \& C-12], 110.8 [C-2], 39.6 [C-14] ppm.

\subsubsection{Synthesis of 4-[(E)-\{[4-(dimethylamino)phenyl] methylidene $\}$ amino $]$ benzoic acid $\left(H L^{6}\right)$}

A similar synthetic procedure to that used for $\mathrm{HL}^{4}$ was used [39] except that anthranilic acid was replaced by 4-aminobenzoic acid. The crude product was then recrystallized from methanol to give a golden yellow powder in $66 \%$ yield. M. p.: $270-272{ }^{\circ} \mathrm{C}$. Anal. calc. for $\mathrm{C}_{16} \mathrm{H}_{16} \mathrm{~N}_{2} \mathrm{O}_{2}: \mathrm{C}, 71.62 ; \mathrm{H}, 6.01 ; \mathrm{N}$, $10.44 \%$. Found. C, 71.72; H, 6.20; N, $10.58 \%$. IR $\left(\mathrm{cm}^{-1}\right): 1680 \mathrm{v}(\mathrm{OCO})_{\mathrm{asym}} .{ }^{1} \mathrm{H}-\mathrm{NMR}\left(\mathrm{CDCl}_{3}+\mathrm{DMSO}-\right.$ $\left.d_{6}\right): \delta_{\mathrm{H}} ; 9.74$ [s, 1H, H-15], 7.83 [d, 2H, H-3 \& H-5], 7.75 [d, 2H, H-9 \& H-13], 6.74 [d, 2H, H-2 \& H-6], 6.67 [d, 2H, H-10 \& H-12], 3.13 [s, 6H, H-14] ppm. Signals for the carboxylic acid were exchanged due to presence of water in the solvent. ${ }^{13} \mathrm{C}-\mathrm{NMR}\left(\mathrm{CDCl}_{3}+\mathrm{DMSO}-d_{6}\right): \delta_{\mathrm{C}} ; 189.7$ [C-1], 168.3 [C-15], 154.0 [C7], 153.0 [C-11], 131.2 [C-3 \& C-5], 124.4 [C-4], 120.7 [C-9], 117.0 [C-13], 112.6 [C-2 \& C-6], 110.8 [C1- \& C-12], 39.5 [C-14] ppm.

\subsection{Synthesis and characterization of triphenyltin(IV) compounds}

A general method was followed for the synthesis of compounds 1-6. In a typical procedure, a mixture of $\mathrm{Ph}_{3} \mathrm{SnOH}$ and the appropriate pro-ligands $\mathrm{HL}^{\mathrm{n}}(\mathrm{n}=1-6)$ in a 1:1 stoichiometric ratio was heated to reflux in anhydrous toluene $(50 \mathrm{~mL})$ for $8 \mathrm{~h}$ in a round bottom flask equipped with a Dean-Stark apparatus and a water-cooled condenser. The reaction mixture was filtered while hot and the solvent was removed using a rotary evaporator. The residue was washed, boiled with hexane, filtered and dried in vacuo. The residue upon crystallization using appropriate solvent(s) yielded the desired product. The specific details pertaining to reactants, analytical and characterization data for the complexes are given below.

\subsection{1. $\mathrm{Ph}_{3} \mathrm{SnL}^{1}(\mathbf{1})$}

The synthesis of 1 has been reported earlier [40] by two different methods, utilizing reactions of $\mathrm{Ph}_{2} \mathrm{SnO}$ and $\mathrm{HL}^{1}$ as well as $\left(\mathrm{Ph}_{3} \mathrm{Sn}\right)_{2} \mathrm{O}$ and $\mathrm{HL}^{1}$, both conducted in ethanol. The yields of the products were $50 \%$ and $68 \%$, respectively, and the melting point was not reported. In the present investigation, 1 was prepared by following a general method described above. $\mathrm{Ph}_{3} \mathrm{SnOH}(0.68 \mathrm{~g}, 1.85 \mathrm{mmol}) ; \mathrm{HL}^{1}$ (0.50 g, 1.85 mmol). Recrystallized from toluene to give a red microcrystalline product in $78 \%$ yield. M.p.: $175-177{ }^{\circ} \mathrm{C}$. Anal. calc. for $\mathrm{C}_{33} \mathrm{H}_{29} \mathrm{~N}_{3} \mathrm{O}_{2} \mathrm{Sn}$ : C, 64.10; H, 4.73; N, $6.80 \%$. Found. C, 63.96; H, 4.70; N, 6.58 \%. IR (cm 
$\left.{ }^{1}\right): 1723 v(\mathrm{OCO})_{\text {asym }}, 1369 v(\mathrm{OCO})_{\text {asym. }}$ Electronic absorption data (benzene) $\lambda_{\max }, \mathrm{nm} ;\left(\varepsilon\left[\mathrm{M}^{-1}\right]\right): 430 \mathrm{sh}$ (3,402), 478 (6,907). ${ }^{1} \mathrm{H}$ NMR $\left(\mathrm{CDCl}_{3}\right) ; \delta_{\mathrm{H}}$ : 7.74-7.52 [m, 8H, H-3, H-6 \& H-2*], 7.44-7.11 [m, 13H, H-4, $\mathrm{H}-5, \mathrm{H}-9, \mathrm{H}-13, \mathrm{H}-3 *$ \& H-4*], 6.52 [d, 2H, H-10 \& H-12], 3.00 [s, 6H, H-14] ppm. ${ }^{13} \mathrm{C}-\mathrm{NMR}\left(\mathrm{CDCl}_{3}\right)$; $\delta_{\mathrm{C}}: 172.6[\mathrm{C}-1], 152.4$ [C-7], 152.1 [C-11], 145.8 [C-8], $137.9\left[{ }^{1} J\left({ }^{13} \mathrm{C}-{ }^{119 / 117} \mathrm{Sn}\right)=640 / 620 \mathrm{~Hz}, \mathrm{C}-1^{*}\right]$, $136.5\left[{ }^{2} J\left({ }^{13} \mathrm{C}^{119 / 117} \mathrm{Sn}\right)=48 \mathrm{~Hz}, \mathrm{C}-2 *\right.$ ] $135.3[\mathrm{ArC}], 131.6[\mathrm{ArC}], 130.2[\mathrm{ArC}], 130.1[\mathrm{ArC}], 129.6\left[{ }^{4} J\right.$ $\left.\left({ }^{13} \mathrm{C}^{-119 / 117} \mathrm{Sn}\right)=13 \mathrm{~Hz}, \mathrm{C}-4 *\right], 128.7[\mathrm{ArC}], 128.6[\mathrm{ArC}], 128.4\left[{ }^{3} J\left({ }^{13} \mathrm{C}^{*}{ }^{119 / 117} \mathrm{Sn}\right)=63 \mathrm{~Hz}, \mathrm{C}-3 *\right], 126.6$ [ArC], 111.0 [ArC], 39.7 [C-14] ppm. ${ }^{119} \mathrm{Sn} \mathrm{NMR}\left(\mathrm{CDCl}_{3}\right) ; \delta_{\mathrm{Sn}}:-109.5 \mathrm{ppm}$.

\subsection{2. $P h_{3} \mathrm{SnL}^{2}$ (2)}

$\mathrm{Ph}_{3} \mathrm{SnOH}$ (0.68 g, $\left.1.85 \mathrm{mmol}\right) ; \mathrm{HL}^{2}(0.50 \mathrm{~g}, 1.85 \mathrm{mmol})$. Recrystallized from toluene to give an orange-red microcrystalline product in $75 \%$ yield. M.p.: $162-163{ }^{\circ} \mathrm{C}$. Anal. calc. for $\mathrm{C}_{33} \mathrm{H}_{29} \mathrm{~N}_{3} \mathrm{O}_{2} \mathrm{Sn}: \mathrm{C}$, 64.10; H, 4.73; N, $6.80 \%$. Found. C, 64.26; H, 4.88; N, $6.78 \%$. IR ( $\left.\mathrm{cm}^{-1}\right): 1615$ v(OCO) asym, 1363 $v(\mathrm{OCO})_{\text {asym. }}$. Electronic absorption data (benzene) $\lambda_{\max }, \mathrm{nm} ;\left(\varepsilon\left[\mathrm{M}^{-1}\right]\right): 418(2,474) .{ }^{1} \mathrm{H} \mathrm{NMR}\left(\mathrm{CDCl}_{3}\right) ; \delta_{\mathrm{H}}$ : 8.53 [s, 1H, H-2], 8.09-7.76 [m, 10H, H-4, H-6, H-9, H-13 \& H-2*], 7.47-7.17 [m, 10H, H-5, H-3* \& H4*], 6.67 [d, 2H, H-10 \& H-12], 3.00 [s, 6H, H-14] ppm. ${ }^{13} \mathrm{C}-\mathrm{NMR}\left(\mathrm{DMSO}-d_{6}+\mathrm{CDCl}_{3}\right.$ ); $\delta_{\mathrm{C}}: 169.0$ [C-1], $152.3[\mathrm{C}-7], 152.2[\mathrm{C}-11], 142.8[\mathrm{C}-8], 142.6\left[{ }^{1} J\left({ }^{13} \mathrm{C}-{ }^{119 / 117} \mathrm{Sn}\right)=630 / 620 \mathrm{~Hz}, \mathrm{C}-1^{*}\right], 136.1\left[{ }^{2} J\left({ }^{13} \mathrm{C}-\right.\right.$ $\left.\left.{ }^{119 / 117} \mathrm{Sn}\right)=45 \mathrm{~Hz}, \mathrm{C}-2 *\right], 130.0[\mathrm{ArC}], 128.7\left[{ }^{4} J\left({ }^{13} \mathrm{C}-{ }^{119 / 117} \mathrm{Sn}\right)=13 \mathrm{~Hz}, \mathrm{C}-4 *\right.$ ] $128.4[\mathrm{ArC}], 128.0\left[{ }^{3} J\left({ }^{13} \mathrm{C}-\right.\right.$ $\left.{ }^{119 / 117} \mathrm{Sn}\right)=65 \mathrm{~Hz}, \mathrm{C}-3 *$ ] $124.9[\mathrm{ArC}], 124.6[\mathrm{ArC}], 122.2[\mathrm{ArC}], 111.1[\mathrm{ArC}], 40.0[\mathrm{C}-14] \mathrm{ppm} .{ }^{119} \mathrm{Sn}$ $\operatorname{NMR}\left(\mathrm{CDCl}_{3}\right) ; \delta_{\mathrm{Sn}}:-107.3 \mathrm{ppm}$.

\subsection{3. $P h_{3} S n L^{3}(3)$}

$\mathrm{Ph}_{3} \mathrm{SnOH}(0.68 \mathrm{~g}, 1.85 \mathrm{mmol}) ; \mathrm{HL}^{3}(0.50 \mathrm{~g}, 1.85 \mathrm{mmol})$. Recrystallized from benzene to give a dark-red microcrystalline product in $76 \%$ yield. M.p.: 214-216 ${ }^{\circ} \mathrm{C}$. Anal. calc. for $\mathrm{C}_{33} \mathrm{H}_{29} \mathrm{~N}_{3} \mathrm{O}_{2} \mathrm{Sn}$ : C, 64.10; H, 4.73; N, $6.80 \%$. Found. C, 64.16; H, 4.80; N, $6.70 \%$. IR $\left(\mathrm{cm}^{-1}\right): 1623 v(\mathrm{OCO})_{\text {asym }}, 1364 v(\mathrm{OCO})_{\text {asym. }}$ Electronic absorption data (benzene) $\lambda_{\max }, \mathrm{nm} ;\left(\varepsilon\left[\mathrm{M}^{-1}\right]\right): 433(5,154) .{ }^{1} \mathrm{H} \mathrm{NMR}\left(\mathrm{CDCl}_{3}\right) ; \delta_{\mathrm{H}}: 8.16[\mathrm{~d}, 2 \mathrm{H}$, H-3 \& H-5], 7.83-7.74 [m, 10H, H-2, H-6, H-9, H-13 \& H-2*], 7.47- 7.25 [m, 9H, H-3* \& H-4*], 6.66 [d, 2H, H-10 \& H-12], 3.01 [s, 6H, H-14] ppm. ${ }^{13} \mathrm{C}-\mathrm{NMR}\left(\mathrm{CDCl}_{3}\right) ; \delta_{\mathrm{C}}: 172.4$ [C-1], 155.8 [C-7], 152.8 [C-11], $143.7[\mathrm{C}-8], 138.4\left[{ }^{1} J\left({ }^{13} \mathrm{C}-{ }^{119 / 117} \mathrm{Sn}\right)=640 / 625 \mathrm{~Hz}, \mathrm{C}-1 *\right], 136.9\left[{ }^{2} J\left({ }^{13} \mathrm{C}^{-1}{ }^{119 / 117} \mathrm{Sn}\right)=48 \mathrm{~Hz}, \mathrm{C}-2 *\right], 130.7$ $[\mathrm{ArC}], 130.2\left[{ }^{4} J\left({ }^{13} \mathrm{C}_{-}{ }^{119 / 117} \mathrm{Sn}\right)=12 \mathrm{~Hz}, \mathrm{C}-4^{*}\right], 128.0\left[{ }^{3} J\left({ }^{13} \mathrm{C}-{ }^{119 / 117} \mathrm{Sn}\right)=63 \mathrm{~Hz}, \mathrm{C}-3 *\right], 125.5[\mathrm{ArC}], 121.8$ [ArC], 111.5 [ArC], 40.3 [C-14] ppm. ${ }^{119} \mathrm{Sn} \mathrm{NMR}\left(\mathrm{CDCl}_{3}\right) ; \delta_{\mathrm{Sn}}:-108.7 \mathrm{ppm}$. 


\subsection{4. $\mathrm{Ph}_{3} \mathrm{SnL}^{4}$ (4)}

$\mathrm{Ph}_{3} \mathrm{SnOH}$ (0.68 g, $\left.1.85 \mathrm{mmol}\right) ; \mathrm{HL}^{4}(0.50 \mathrm{~g}, 1.86 \mathrm{mmol})$. Recrystallized from benzene to give an orange-red powder in $76 \%$ yield. M.p.: $144-146{ }^{\circ} \mathrm{C}$. Anal. calc. for $\mathrm{C}_{34} \mathrm{H}_{30} \mathrm{~N}_{2} \mathrm{O}_{2} \mathrm{Sn}: \mathrm{C}, 66.15 ; \mathrm{H}, 4.90 ; \mathrm{N}$, $4.54 \%$. Found. C, 66.16; H, 4.80; N, $4.70 \%$. IR $\left(\mathrm{cm}^{-1}\right): 1639 v(\mathrm{OCO})_{\text {asym }}, 1367 v(\mathrm{OCO})_{\text {asym. Electronic }}$ absorption data (benzene) $\lambda_{\max }, \mathrm{nm} ;\left(\varepsilon\left[\mathrm{M}^{-1}\right]\right): 416(7,010) .{ }^{1} \mathrm{H}$ NMR $\left(\mathrm{CDCl}_{3}\right) ; \delta_{\mathrm{H}}: 8.28[\mathrm{~s}, 1 \mathrm{H}, \mathrm{H}-15], 7.88$ [d, 1H, H-3], 7.80-7.40 [m, 6H, H-2*], 7.44-7.30 [m, 12H, H-4, H-9, H-13, H-3* \& H-4*], 7.14 [t, 1H, H5], 6.85-6.50 [m, 3H, H-6, H-10 \& H-12], 3.10-2.90 [s, 6H, H-14] ppm. ${ }^{13} \mathrm{C}-\mathrm{NMR}\left(\mathrm{CDCl}_{3}\right)$; $\delta_{\mathrm{C}}: 191.1$ [C1], 161.8 [C-15], 153.3 [C-7], $147.0[\mathrm{C}-11], 139.0\left[{ }^{1} J\left({ }^{13} \mathrm{C}^{-19 / 117} \mathrm{Sn}\right)=585 / 570 \mathrm{~Hz}, \mathrm{C}-1^{*}\right], 137.6\left[{ }^{2} J\left({ }^{13} \mathrm{C}-\right.\right.$ $\left.\left.{ }^{119 / 117} \mathrm{Sn}\right)=47 \mathrm{~Hz}, \mathrm{C}-2^{*}\right], 131.4[\mathrm{ArC}], 131.3[\mathrm{ArC}], 130.8\left[{ }^{4} J\left({ }^{13} \mathrm{C}-{ }^{119 / 117} \mathrm{Sn}\right)=13 \mathrm{~Hz}, \mathrm{C}-4 *\right], 129.8[\mathrm{ArC}]$, 129.7 [ArC], $129.6\left[{ }^{3} J\left({ }^{13} \mathrm{C}-{ }^{119 / 117} \mathrm{Sn}\right)=63 \mathrm{~Hz}, \mathrm{C}-3 *\right.$ ] 122.8 [ArC], 121.5 [ArC], 117.4 [ArC], 112.2 [ArC], 111.6 [ArC], 40.8 and 40.7 [C-14] ppm. $\left.{ }^{119} \mathrm{Sn} \mathrm{NMR}\left(\mathrm{CDCl}_{3}\right)\right)$; $\delta_{\mathrm{Sn}}:-109.5 \mathrm{ppm}$.

\subsection{5. $P h_{3} S n L^{5}(5)$}

$\mathrm{Ph}_{3} \mathrm{SnOH}(0.68 \mathrm{~g}, 1.85 \mathrm{mmol}) ; \mathrm{HL}^{5}(0.50 \mathrm{~g}, 1.86 \mathrm{mmol})$. Recrystallized from acetonitrile to give a dark-orange crystalline material in $71 \%$ yield. M.p.: $184-186{ }^{\circ}$ C. Anal. calc. for $\mathrm{C}_{34} \mathrm{H}_{30} \mathrm{~N}_{2} \mathrm{O}_{2} \mathrm{Sn}$ : C, 66.15 ; H, 4.90; N, 4.54 \%. Found. C, 65.96; H, 4.80; N, $4.60 \%$. IR $\left(\mathrm{cm}^{-1}\right): 1629 v(\mathrm{OCO})_{\text {asym }}, 1332 v(\mathrm{OCO})_{\text {asym. }}$ Electronic absorption data (benzene) $\lambda_{\max }, \mathrm{nm} ;\left(\varepsilon\left[\mathrm{M}^{-1}\right]\right): 434(4,639) .{ }^{1} \mathrm{H}-\mathrm{NMR}\left(\mathrm{CDCl}_{3}\right): \delta_{\mathrm{H}} ; 8.37[\mathrm{~s}, 1 \mathrm{H}$, H-15], 7.96 [d, 1H, H-4], 7.85-7.70 [m, 7H, H-2 \& H-2*], 7.60-7.40 [m, 10H, H-5, H-3* \& H4*], 7.25-7.21 [m, 2H, H-9, H-13], 6.87 [d, 1H, H-6], 6.80-6.70 [m, 2H, H-10 \& H-12], 3.09-3.07 [s, 6H, H-14] ppm. ${ }^{13} \mathrm{C}-$ NMR $\left(\mathrm{CDCl}_{3}+\mathrm{DMSO}-d_{6}\right): \delta_{\mathrm{C}} ; 190.1$ [C-1], 160.6 [C-15], 154.6 [C-11], 152.8 [C-7], 143.3 [C-9 \& C-13], $137.3\left[{ }^{1} J\left({ }^{13} \mathrm{C}^{119 / 117} \mathrm{Sn}\right)=630 / 620 \mathrm{~Hz}, \mathrm{C}-\mathrm{I}^{*}\right], 136.8\left[{ }^{2} J\left({ }^{13} \mathrm{C}-{ }^{119 / 117} \mathrm{Sn}\right)=42 \mathrm{~Hz}, \mathrm{C}-2 *\right], 130.8[\mathrm{ArC}], 129.6$ $[\mathrm{ArC}], 129.3\left[{ }^{4} J\left({ }^{13} \mathrm{C}-{ }^{119 / 117} \mathrm{Sn}\right)=13 \mathrm{~Hz}, \mathrm{C}-4 *\right], 128.6\left[{ }^{3} J\left({ }^{13} \mathrm{C}-{ }^{119 / 117} \mathrm{Sn}\right)=65 \mathrm{~Hz}, \mathrm{C}-3 *\right], 124.9$ [ArC $], 118.4$ [ArC], 115.8 [ArC], 111.7 [ArC], 111.3 [ArC], 40.2 [C-14] ppm. ${ }^{119} \mathrm{Sn}$ NMR $\left(\mathrm{CDCl}_{3}\right) ; \delta_{\mathrm{Sn}}:-108.7 \mathrm{ppm}$.

\subsection{6. $P h_{3} S n L^{6}(\mathbf{6})$}

$\mathrm{Ph}_{3} \mathrm{SnOH}$ (0.68 g, $\left.1.85 \mathrm{mmol}\right) ; \mathrm{HL}^{6}(0.50 \mathrm{~g}, 1.86 \mathrm{mmol})$. Recrystallized from acetonitrile to give a golden-yellow crystalline material in 71\% yield. M.p.: $189-190{ }^{\circ} \mathrm{C}$. Anal. calc. for $\mathrm{C}_{34} \mathrm{H}_{30} \mathrm{~N}_{2} \mathrm{O}_{2} \mathrm{Sn}: \mathrm{C}, 66.15$; H, 4.90; N, 4.54 \%. Found. C, 66.26; H, 4.80; N, $4.68 \%$. IR $\left(\mathrm{cm}^{-1}\right): 1632 v(\mathrm{OCO})_{\text {asym }}, 1370 v(\mathrm{OCO})_{\text {asym. }}$ Electronic absorption data (benzene) $\lambda_{\max }, \mathrm{nm} ;\left(\varepsilon\left[\mathrm{M}^{-1}\right]\right): 452(14,444) .{ }^{1} \mathrm{H}-\mathrm{NMR}\left(\mathrm{CDCl}_{3}\right): \delta_{\mathrm{H}} ; 8.40[\mathrm{~s}, 1 \mathrm{H}$, H-15], 8.26 [d, 2H, H-3 \& H-5], 7.94-7.92 [m, 6H, H-2*], 7.88 [d, 2H, H-9 \& H-13], 7.53-7.50 [m, 9H, H$3^{*} \& \mathrm{H} 4 *$ ] 7.29 [d, 2H, H-2 \& H-6], 6.83 [d, 2H, H-10 \& H-12], 3.16 [s, 6H, H-14] ppm. ${ }^{13} \mathrm{C}-\mathrm{NMR}$ $\left(\mathrm{CDCl}_{3}\right): \delta_{\mathrm{C}} ; 190.1[\mathrm{C}-1], 160.8$ [C-15], $152.6[\mathrm{C}-7], 152.3[\mathrm{C}-11], 138.0\left[{ }^{1} J\left({ }^{13} \mathrm{C}-{ }^{119 / 117} \mathrm{Sn}\right)=635 / 620 \mathrm{~Hz}\right.$, $\left.\mathrm{C}-1^{*}\right], 136.6\left[{ }^{2} J\left({ }^{13} \mathrm{C}-{ }^{119 / 117} \mathrm{Sn}\right)=48 \mathrm{~Hz}, \mathrm{C}-2^{*}\right], 135.4[\mathrm{ArC}], 129.8\left[{ }^{4} J\left({ }^{13} \mathrm{C}^{1}{ }^{119 / 117} \mathrm{Sn}\right)=13 \mathrm{~Hz}, \mathrm{C}-4 *\right], 128.8$ 
[ArC], $128.7[\mathrm{ArC}], 128.6\left[{ }^{3} J\left({ }^{13} \mathrm{C}-{ }^{119 / 117} \mathrm{Sn}\right)=62 \mathrm{~Hz}, \mathrm{C}-3 *\right.$ ] 124.7 [ArC], 120.5 [ArC], 116.4 [ArC], 111.2 [ArC], 110.6 [ArC], 39.8 [C-14] ppm. ${ }^{119} \mathrm{Sn} \mathrm{NMR}\left(\mathrm{CDCl}_{3}\right) ; \delta_{\mathrm{sn}}:-107.5 \mathrm{ppm}$.

\subsection{X-ray crystallography}

Single crystals suitable for an X-ray crystal structure determination were obtained from methanol $\left(\mathrm{HL}^{4}\right.$ and 2) and acetonitrile (5) solutions of the respective compounds by slow evaporation of the solvent at room temperature. Intensity data for $\mathrm{HL}^{4}, \mathbf{2}$ and $\mathbf{5}$ were collected at room temperature on an Agilent Xcalibur Eos Gemini diffractometer equipped with a CCD area detector and graphite-monochromated Mo K $\alpha$ radiation $(\lambda=0.71073 \AA$ ). Data reduction and empirical absorption correction, based on a multi-scan technique, was by standard methods [41]. The structures were solved by direct methods using SHELXS97 [42] and refinement (anisotropic displacement parameters and C-bound hydrogen atoms in idealised positions) of each structure was carried out on $F^{2}$ by using the full-matrix least-squares procedure incorporated in SHELXL2014/7 [43]. The hydroxyl-H atom in $\mathrm{HL}^{4}$ was located from a difference Fourier map and refined with the distance restraint $\mathrm{O}-\mathrm{H}=0.82 \pm 0.01 \AA$. A weighting scheme of the form $w=$ $1 /\left[\sigma^{2}\left(F_{\mathrm{o}}{ }^{2}\right)+(a P)^{2}+b P\right]$ where $P=\left(F_{\mathrm{o}}{ }^{2}+2{F_{\mathrm{c}}}^{2}\right) / 3$ was introduced in each case. The final difference maps of $\mathrm{HL}^{4}$ and 2 exhibited no special features, but some evidence was found for disorder in the C41-phenyl ring of 5, as manifested by shorter than usual $\mathrm{C}-\mathrm{C}$ bond lengths. However, multiple positions for the atoms comprising the C41-ring were not resolved in this room temperature determination. Crystal data and refinement details are given in Table 1. Molecular structure diagrams, showing the atom labelling schemes, were drawn with 50\% displacement ellipsoids using ORTEP-3 for Windows [44] and the remaining crystallographic figures were drawn with DIAMOND [45]. Data manipulation and interpretation were accomplished using WinGX [44] and PLATON [46].

\section{Insert Table 1}

\subsection{Experimental protocol and cytotoxicity tests}

\subsubsection{Stability assessment of triphenyltin(IV) compounds 1-6 in DMSO solution}

As mentioned in the introduction, the organotin(IV) compounds are dissolved in DMSO and diluted with test medium prior to in vitro testing and hence the stabilities of the triphenyltin(IV) compounds 1-6 were assessed in DMSO prior to the cytotoxic studies. The absorbance spectra obtained from UV/Vis were monitored for 23 days (Fig. S1, ESI), with the unchanged basic pattern of the spectra of compounds indicating the compounds are stable in DMSO solution. 


\subsubsection{MTT assays}

MDA-MB 231, HeLa and HEK293 cell lines were used to determine cytotoxicity. The cell viability was checked by the MTT assay (colorimetric assay) based on the conversion of the yellow tetrazolium salt MTT to purple formazan crystals after reaction with mitochondrial dehydrogenase of metabolically active cells [47]. Stock solutions of pro-ligands, $\mathrm{HL}^{\mathrm{n}}$ and their compounds 1-6, and $\mathrm{Ph}_{3} \mathrm{SnOH}$ were prepared in DMSO and diluted with DMEM (a culture medium comprising 10\% fetal bovine serum,

supplemented with $20 \mathrm{mM}$ L-glutamine, 100 units per $\mathrm{mL}$ penicillin and $100 \mu \mathrm{g} \mathrm{mL}^{-1}$ streptomycin) such that the final concentration of DMSO did not exceeded $0.1 \% \mathrm{v} / \mathrm{v}$. The cell lines were maintained in complete DMEM at $37{ }^{\circ} \mathrm{C}$ under a humidified atmosphere of $5 \% \mathrm{CO}_{2}$. Briefly, $1 \times 10^{4} \mathrm{HeLa}$, MDA-MB 231 and HEK293 cells were seeded in three different 96 well cell culture plates. After $24 \mathrm{~h}$, the culture medium was replaced by a fresh medium containing various concentrations of $\mathrm{HL}^{\mathrm{n}}$ and 1-6 and, incubated further for $24 \mathrm{~h}$ in $5 \% \mathrm{CO}_{2}$ humidified atmosphere. The medium was then removed and $100 \mu \mathrm{L}$ of fresh medium and $10 \mu \mathrm{L}$ of $5 \mathrm{mg} \mathrm{mL}^{-1}$ MTT in phosphate buffered saline (PBS, pH 7.4) were added to each well and incubated further for $2 \mathrm{~h}$. Finally, $100 \mu \mathrm{L}$ of DMSO was added to dissolve the MTT formazan crystals followed by incubation for $30 \mathrm{~min}$. Similarly; the MDA-MB 231 and HeLa cells were exposed to various concentrations of CDDP as the drug control. The absorbance of samples was measured at $570 \mathrm{~nm}$ with a plate reader. The percent cell inhibition was calculated with respect to control and $\mathrm{IC}_{50}$ (inhibitory concentration) values obtained were represented as mean \pm SD for triplicates.

\subsubsection{ROS generation assay}

The intracellular ROS level was assessed using DCFH-DA. Briefly, MDA-MB 231, HeLa and HEK 293 cells were seeded in 6 well plates at a density of $4 \times 10^{5}$ cells per well for $24 \mathrm{~h}$ at $37{ }^{\circ} \mathrm{C}$ in a humidified atmosphere of $5 \% \mathrm{CO}_{2}$. Then, HeLa cells were treated with complex 5 with concentrations of $0.6,0.8$ and $1.0 \mu \mathrm{M}$ (based on the $\mathrm{IC}_{50}$ value) for $24 \mathrm{~h}$. Similarly, the MDAMB- 231 cells were then treated with the compounds 1 and 3 with concentrations of $0.5,1.0$ and $1.5 \mu \mathrm{M}$ (based on the $\mathrm{IC}_{50}$ values) and HEK 293 cells were treated with compounds $\mathbf{1}, \mathbf{3}$ and $\mathbf{5}$ at the $\mathrm{IC}_{50}$ concentrations obtained against the cancer cells for $24 \mathrm{~h}$ at $37{ }^{\circ} \mathrm{C}$ maintaining the humidified atmosphere of $5 \% \mathrm{CO}_{2}$. Then, the cells were washed with PBS and they were exposed in DCFH-DA dye $(10 \mu \mathrm{M})$ for $30 \mathrm{~min}$ at $37^{\circ} \mathrm{C}$. The cell samples were subjected to inverted fluorescence microscopy and DCF fluorescence was detected $\left(\lambda_{\mathrm{ex}}=485 \mathrm{~nm} ; \lambda_{\mathrm{em}}\right.$ $=530 \mathrm{~nm}$ ) and photographed. 


\subsubsection{Fluorescence staining of MDAMB-231 and HeLa cells for the detection of apoptotic cell death}

The MDAMB-231 and HeLa cells $\left(2 \times 10^{5}\right)$ were seeded in 6 well plates and kept for $24 \mathrm{~h}$ at 37 ${ }^{\circ} \mathrm{C}$ in a humidified atmosphere of $5 \% \mathrm{CO}_{2}$. Thereafter, cells were treated with the indicated concentrations of 1, 3 and 5 for $24 \mathrm{~h}$. Subsequently, cells were washed with 1 x PBS and stained with Hoechst 33342 (10 $\left.\mu \mathrm{g} \mathrm{mL}{ }^{-1}\right)$ and PI $\left(15 \mu \mathrm{g} \mathrm{mL}^{-1}\right)$ solutions and incubated at $37{ }^{\circ} \mathrm{C}$ for $20 \mathrm{~min}$. Cells were then washed with PBS and images of nuclear morphology were recorded using an inverted fluorescent microscope in red and blue channels.

\subsubsection{Flow cytometry analysis of apoptosis}

The MDAMB-231 and HeLa cells $\left(2 \times 10^{5}\right)$ were seeded in 12 well plates separately, as described above, and then treated with various concentrations of $\mathbf{1 , 3}$ and $\mathbf{5}$, respectively, for $24 \mathrm{~h}$ and incubated in a $\mathrm{CO}_{2}$ incubator. After incubation, cells were washed with ice-cold PBS and harvested. The cells were centrifuged at $3000 \mathrm{rpm}$ for $10 \mathrm{~min}$. The cells were re-suspended in $100 \mu \mathrm{L}$ of annexin binding buffer wherein $5 \mu \mathrm{L}$ of annexin V Alexa fluor 488 conjugate and $1 \mu \mathrm{L}$ of PI $\left(100 \mu \mathrm{g} \mathrm{mL}^{-1}\right)$ was added and incubated for $15 \mathrm{~min}$ at $37{ }^{\circ} \mathrm{C}$ in the dark. Finally, $400 \mu \mathrm{L}$ of annexin binding buffer was added in each tube and the stained cells were analyzed by flow cytometry.

\subsubsection{Cell cycle analysis}

The MDAMB-231 and HeLa cells $\left(4 \times 10^{5}\right)$ were seeded in 6 well plates as described above, and then treated with indicated concentrations of 1, 3 and 5 for $24 \mathrm{~h}$ in DMEM with 10\% FBS. Cells were then washed, trypsinized and fixed in ice-cold $70 \%$ ethanol and kept overnight at $-20{ }^{\circ} \mathrm{C}$. Then, the cells were washed twice in ice-cold PBS, and $500 \mu \mathrm{L}$ of staining solution $(0.1 \%(\mathrm{v} / \mathrm{v})$ Triton X-100 solution, PI (1 mg

$\left.\mathrm{mL}^{-1}\right)$ solution and RNase $\left(10 \mathrm{mg} \mathrm{mL}^{-1}\right.$ in PBS)) were added to each sample and incubated for $30 \mathrm{~min}$ at room temperature in the dark. After the staining procedure, the cell samples were assessed and the cell cycle distribution was analyzed using a FACS Aria II flow cytometer and analyzed using CELLQUEST software.

\section{Results and discussion}

\subsection{Syntheses and spectroscopy}

In the present investigation, potential for influencing cytotoxicity was the motivation for combining the effects of triphenyltin esters, being located in ortho-, meta- and para- positions of molecules, with a diazenyl- or its isoelectronic imino group linking the aryl moieties (Fig. 1). Thus, six proligands containing diazenyl- and imino groups were selected, as these are likely to impart efficacious 
biological activities [48-50]. The synthesis of pro-ligands, such as 2-\{(E)-2-[4(dimethylamino)phenyl]diazenyl benzoic acid and its meta- and para-derivatives $\left(\mathrm{HL}^{1}-\mathrm{HL}^{3}\right)$ were achieved via a single-step procedure by reacting the appropriate carboxybenzenediazonium chloride with dimethyl aniline, using diazo-coupling reactions. On the other hand, 2-[(E)-\{[4(dimethylamino)phenyl]methylidene amino]benzoic acid and their derivatives $\left(\mathrm{HL}^{4}-\mathrm{HL}^{6}\right)$ were synthesized by condensing the appropriate aniline with 4-(dimethylamino)benzaldehyde [39]. Crystalline triphenyltin esters (1-6) were synthesized by reacting equimolar amounts of $\mathrm{Ph}_{3} \mathrm{SnOH}$ with $\mathrm{HL}^{\mathrm{n}}, \mathrm{n}=1-6$, in anhydrous toluene. Compounds were isolated as coloured crystalline solids in high yield. They are stable in air and soluble in common polar and non-polar organic solvents. Diagnostically significant spectral features were apparent. The IR spectra of compounds 1-6 each displayed a strong sharp band in the range $1615-1640 \mathrm{~cm}^{-1}$ for the $\left[v(\mathrm{OCO})_{\text {asym }}\right]$ while a band due to $\left[v(\mathrm{OCO})_{\text {sym }}\right]$ was detected in the range $1332-1370 \mathrm{~cm}^{-1}$ (refer to the experimental section for specific values). The observed differences, i.e. $\Delta\left(v_{\text {asym }}-v_{\text {sym }}\right)$ in compounds 16 are 254,252,259,272, 297 and $262 \mathrm{~cm}^{-1}$, respectively, are indicative of an unidentate mode of coordination of carboxylate oxygen to the tin atom [51]. This inference is further supported by the correlation recently ascertained by Watkinson et al. [52] ( $\Delta$ range from $107-565 \mathrm{~cm}^{-1}$ for unidentate and 45 $299 \mathrm{~cm}^{-1}$ for bidentate bridging mode). In the present study, the unidentate bonding modes of carboxylate ligands were subsequently confirmed from the results of single crystal X-ray diffractions data of representative compounds $\mathbf{2}$ and $\mathbf{5}$, in conjunction with a previously determined structure of $\mathbf{1}$ [40]. The ${ }^{1} \mathrm{H}$ NMR integration values were entirely consistent with the formulation of the products and displayed expected resonances with no unusual features. The ${ }^{13} \mathrm{C}\left\{{ }^{1} \mathrm{H}\right\}$ NMR spectra displayed a carboxylate carbonyl carbon resonance at around $172 \mathrm{ppm}$ for compounds $\mathbf{1}$ and $\mathbf{3}$ in $\mathrm{CDCl}_{3}$ while an upfield shift of this signal was noted for 2 , appearing at $169 \mathrm{ppm}$ in $\mathrm{CDCl}_{3} / \mathrm{DMSO}-d_{6}$ solvents. On the other hand, the carbonyl carbon resonances were detected at around 190 ppm in imino-analogues 4-6 and additionally a signal in the range 154-160 ppm was due to the imino carbon. Triphenyltin(IV) compounds 1-6 all share similar tetrahedral structural features in $\mathrm{CDCl}_{3}$ solution [53,54] as evidenced by ${ }^{119} \mathrm{Sn}$ NMR which in each case featured a sharp singlet in the narrow range of -107.3 to $-109.5 \mathrm{ppm}$.

\subsection{Description of the X-ray crystal structures}

Pro-ligand $\mathrm{HL}^{4}$ and two representative compounds $\mathrm{Ph}_{3} \mathrm{SnL}^{2}$ (2) and $\mathrm{Ph}_{3} \mathrm{SnL}^{5}$ (5) were analyzed by single crystal X-ray crystallography while the crystallographic structures of $\mathbf{3}, \mathbf{4}$ and $\mathbf{6}$ could not be solved owing to the poor quality of data sets. The molecular structure of $\mathrm{HL}^{4}$, Fig. 2, exhibits a small twist about the $\mathrm{C} 2-\mathrm{N} 1$ bond as seen in the $\mathrm{C} 3-\mathrm{C} 2-\mathrm{N} 1-\mathrm{C} 8$ torsion angle of $9.7(3)^{\circ}$ leading to a dihedral angle of $10.39(11)^{\circ}$ between the aromatic rings. The conformation about the imine-C8-N1 bond, 1.283(2) $\AA$, is $E$; 
other salient geometric parameters are collected in the figure caption. The carboxylic acid groups lies in the plane of aryl ring to which it is connected as seen in the $\mathrm{O} 1-\mathrm{C} 7-\mathrm{C} 1-\mathrm{C} 2$ torsion angle of $-6.0(3)^{\circ}$, a conformation which facilitates the formation of an intramolecular hydroxyl-O-H...N(imine) hydrogen bond. In the molecular packing, supramolecular chains mediated by comparatively strong aryl-C$\mathrm{H} . . . \mathrm{O}$ (carbonyl) interactions are formed along [ $\left.\begin{array}{lll}1 & 1 & 1\end{array}\right]$, Fig. S2a, ESI. The chains are connected into supramolecular tubes by methyl-C-H... $($ aryl) contacts, Fig. S2b, ESI and these pack with no specific interactions between them; the closest separations between aryl rings being $>4.8 \AA$, Fig. S2c, ESI. The molecular structure of the diazo analogue of $\mathrm{HL}^{4}$, namely 2-\{(E)-2-[4(dimethylamino)phenyl]diazenyl\}benzoic acid $\left(\mathrm{HL}^{1}\right)$, has been determined previously by X-ray crystallography [55]. The structure presents essentially the same features as for $\mathrm{HL}^{4}$. The dihedral angle between the aryl rings is $12.86(11)^{\circ}$ with the twist in the molecule occurring at the $\mathrm{N}-\mathrm{C}$ bond involving the 4-dimethylamino-aryl ring; the $\mathrm{N}-\mathrm{N}-\mathrm{C}-\mathrm{C}$ torsion angle $=6.8(4)^{\circ}$. The intramolecular hydroxyl-OH...N(imine) hydrogen bond persists.

The molecular structure of the triphenyltin(IV) compound of the anion derived from $\mathrm{HL}^{2}$, i.e. $\mathbf{2}$, is illustrated in Fig. 3 and selected geometric parameters are included in the figure caption. The tin atom is tetrahedrally coordinated within a $\mathrm{C}_{3} \mathrm{O}$ donor set, implying a monodentate mode of coordination of the carboxylate ligand. This assignment is supported by the disparity of over $0.6 \AA$ in the $\mathrm{Sn}-\mathrm{O} 1$ and $\mathrm{Sn}$...O2

Insert Figs. 2 and 3

separations, i.e. 2.0705(18) and 2.6529(17) $\AA$. The C-O1, O2 bond lengths also differ significantly consistent with the presence of a carbonyl-O2 atom. Further, the distortions from a regular tetrahedral geometry are not great as seen in the range of the $\mathrm{O} 1-\mathrm{Sn}-\mathrm{C}$ angles of $94.86(9)$ to $116.16(9)^{\circ}$ and, in particular, of $\mathrm{C}-\mathrm{Sn}-\mathrm{C}$ angles, i.e. $108.80(10)$ to $115.41(10)^{\circ}$. A slightly reduced twist is found in the organic residue of the carboxylate ligand compared with that found in the free carboxylic acid [55] is noted and as seen in the $\mathrm{C} 4-\mathrm{C} 3-\mathrm{N} 1-\mathrm{N} 2$ torsion angle of $-4.6(4)^{\circ}$ with the twist occurring in the benzoate-C$\mathrm{N}(\mathrm{azo})$ bond; the carboxylate is co-planar with the ring it is connected to with the $\mathrm{C} 6-\mathrm{C} 1-\mathrm{C} 7-\mathrm{O} 2$ torsion angle being $179.8(2)^{\mathrm{o}}$. The conformation about the diazo bond is $E$, as for the free ligand, and the $\mathrm{N} 1=\mathrm{N} 2$ bond length is slightly reduced at 1.254(3) $\AA c f$. 1.279(2) $\AA$. The carbonyl-O2 atom does not form a significant intermolecular interaction in the molecular packing but it participates in a close intramolecular $\mathrm{C} 26-\mathrm{H} . . . \mathrm{O} 2$ contact of $2.52 \AA$. The aryl rings of the carboxylate ligand are connected into a supramolecular chain along the $a$-axis via $\pi \ldots \pi$ interactions; the chain is reinforced by $\mathrm{C}-\mathrm{H} \ldots \pi$ interactions involving the tin-bound phenyl rings. Further $\mathrm{C}-\mathrm{H} \ldots \pi$ interactions involving tin-bound 
phenyls results in a supramolecular layer in the $a c$-plane; a view of the unit cell contents is shown in Fig. S3, ESI.

The structure of 5, illustrated in Fig. 4, presents much the same features as for 2. A disordered tetrahedral geometry is observed with the Sn...O2 separation being 2.723(2) $\AA$ cf. 2.068(2) $\AA$ for Sn-O1; the disparity in the $\mathrm{C} 7-\mathrm{O} 1, \mathrm{O} 2$ bond lengths persist. The ranges of $\mathrm{O}-\mathrm{Sn}-\mathrm{C}$ and $\mathrm{C}-\mathrm{Sn}-\mathrm{C}$ bond angles are 93.17(9) to $114.81(10)$ and $110.66(11)$ to $115.44(11)^{\circ}$, respectively. The configuration about the imine $\mathrm{C} 8-$ $\mathrm{N} 1$ bond is $E$ and the bond length of 1.244(5) $\AA$ is shorter than that in $\mathrm{HL}^{4}$. By contrast to the overall conformation in $\mathrm{HL}^{4}$, the carboxylate in $\mathbf{5}$ is highly twisted as manifested in the dihedral angle between the aryl rings of $51.83(17)^{\circ}$. There is also a twist between the carboxylate group and the ring to which it connected as seen in the $\mathrm{C} 2-\mathrm{C} 1-\mathrm{C} 7-\mathrm{O} 2$ torsion angle of $12.1(5)^{\circ}$. By contrast to 2 , the carbonyl-O2 atom participates in a significant intermolecular interaction in the molecule packing of $\mathbf{5}$, forming a tin-boundphenyl-C-H...O contact, leading to a helical supramolecular chain along the $b$-axis. Chains are connected into a three-dimensional architecture by methyl- and tin-bound-phenyl-C-H... $\pi($ aryl) interactions where the accepting aryl rings are tin-bound-phenyl and both rings of the carboxylate ligand, see Fig. S4, ESI.

\section{Insert Fig. 4}

A crystal structure determination is available for 1 [40]. The weakly associated $\mathrm{O} 2$ atom in the distorted tetrahedral geometry is $2.827(3) \AA$ from tin, i.e. further away than in 5, a result that might be correlated with steric pressure. The structure of the tri-n-butyl analogue is also known [56]. This is a polymeric compound as a result of bidentate, bridging carboxylate ligands leading to a trans $-\mathrm{C}_{3} \mathrm{O}_{2}$ donor set for tin and represents one of the two extremes for the overwhelming majority of triorganotin carboxylates, viz. polymeric, five coordinate on the one hand and monomeric, four coordinate on the other [57]. The structures of $\mathbf{1}, \mathbf{2}$ and $\mathbf{5}$ are examples of an intermediate geometry reflecting the close proximity of the carbonyl-O atom to tin. If the carboxylate ligands were considered bidentate, the geometry would be based on a cis $-\mathrm{C}_{3} \mathrm{O}_{2}$ donor set. While there is no precedent for other organotin structures with the metaisomeric carboxylate, one exists for the para-isomer. Here, a monodentate mode of coordination is found in its compound with $\quad\{[(2$-dimethylaminomethyl)phenyl $]$ (diphenyl) $\}$ tin(IV)-4-(4'dimethylaminophenylazo)benzoate [58]. In the same way, there is only one literature precedent for the carboxylate ligand in $\mathbf{5}$, namely in the unusual compound featuring three distinct, monodentate carboxylate ligands, (2-aminobenzoato)-[2-(4-dimethylaminobenzalidine)benzoato]-(2ammoniobenzoate)dimethyltin(IV) [59]. No precedents exist for organotin compounds with the meta- and para-isomeric carboxylate ligands. 


\subsection{Evaluation of in vitro cytotoxicity}

\subsubsection{MTT assay}

The efficacy of triphenyltin(IV) compounds in suppressing tumor cells and advancing apoptosis has been well recognized [24-29]. Cytotoxic data for 1 and its pro-ligand $\mathrm{HL}^{1}$ on HCV29T (human bladder carcinoma) cell line has been reported briefly [40]. In the present investigation, the in vitro cytotoxic activities were evaluated using the MTT assay after incubation of $24 \mathrm{~h}$. $\mathrm{IC}_{50}$ values are given in Table 2 while dose-dependent cytotoxic effects of triphenyltin(IV) compounds 1-6 on MDAMB-231 and HeLa are depicted in Fig. 5. Thus, it is clear that the compounds 1-6 exhibited considerable cytotoxicity in the sub-micromolar concentration range against the cell lines studied.

\section{Insert Fig. 5}

Among the test compounds included in the present investigation, $\mathbf{1}$ and $\mathbf{3}$ displayed significant inhibitory effects on the proliferation of the MDAMB-231 and HeLa cell lines in a dose-dependent manner and were found to be more potent than the clinically used drug, CDDP. The cytotoxicity of each of 1 and 3 was more pronounced against the MDAMB-231 cells at lower concentrations $\left(\mathrm{IC}_{50}=1.19\right.$ and $1.44 \mu \mathrm{M}$, respectively) while for HeLa cells the $\mathrm{IC}_{50}$ values were $\approx 2 \mu \mathrm{M} ; 2$ did not show cytotoxicity up to $2 \mu \mathrm{M}$ regardless of the cell lines explored. On the other hand, 5 exhibited dose-dependent toxicity for both MDAMB-231 and HeLa cell lines with $\mathrm{IC}_{50}$ values of $2.30 \mu \mathrm{M}$ and $0.88 \mu \mathrm{M}$, respectively. However, 4 and 6 exhibited toxicity at very high concentrations. The encouraging $\mathrm{IC}_{50}$ values for $\mathbf{1}, \mathbf{3}$ and $\mathbf{5}$ prompted the determination of their cytotoxicity towards normal cells and indeed they did not induce cytotoxicity in the normal human kidney cells (HEK 293 cell line), up to a concentration of $3.2 \mu \mathrm{M}$ with cell viability up to $60 \%$ (Fig. S5, ESI). It may be concluded that at low concentrations, $\mathbf{1}$ and $\mathbf{3}$ are potent cytotoxic agents for MDAMB-231 cells while $\mathbf{5}$ is potent towards HeLa cells and, therefore further experiments were conducted to ascertain the modes of cell death induced by $\mathbf{1 , 3}$ and $\mathbf{5}$.

\subsubsection{Induction of ROS in MDAMB-231 and HeLa cells}

ROS are generally considered to be deleterious to cells, but ROS also have an important role in regulating signal transduction pathways and gene expressions. However, to effectively target cancer cells specific ROS-sensing signalling pathways that mediate the diverse stress-regulated cellular functions need to be identified [60,61]. Organotin(IV) compounds are known to induce apoptosis by increasing the intracellular ROS level [62]. The level of ROS induced in MDAMB-231 and HeLa cells by $\mathbf{1}$ and $\mathbf{3}$ at concentrations of $0.5,1.0$ and $1.5 \mu \mathrm{M}$, and 5 at concentrations of $0.6,0.8$ and $1.0 \mu \mathrm{M}$, respectively, were monitored using the probe DCFH-DA. DCFH-DA hydrolyzes to 2,7-dichlorodihydrofluorescein (DCFH) 
in live cells, which in turn is oxidized to 2,7-dichlorofluorescein (DCF) in the presence of ROS, exhibiting a green fluorescence [63,64]. As compared to the control, a noteworthy increase in ROS level was induced by $\mathbf{1}$ and $\mathbf{3}$ in MDAMB-231 cell and $\mathbf{5}$ in HeLa cells (Fig. 6). The investigated compounds also displayed an elevated level of ROS generation in a dose-dependent manner in the respective cell lines with respect to the control, which could be one of the reasons that apoptosis is promoted in these cells. Further, generation of ROS was also measured in normal HEK 293 cells at their $\mathrm{IC}_{50}$ concentration obtained against cancer cell and it was observed that the compounds did not induce increased ROS production (Fig. S6, ESI), as compared to the cancer cells (Fig. 6) besides a few cells showing basal ROS induction.

\section{Insert Fig. 6}

\subsubsection{Assessment of nuclear morphology during apoptosis by Hoechst 33342 and PI staining}

The apoptotic mode of cell death leads to distinct morphological and biochemical features, which are accompanied by nuclear shrinkage, cytoplasmic membrane blabbing, chromatin condensation, fragmentation of the nucleus, etc. $[65,66]$. To ascertain the intricacies of nuclear morphological changes during apoptosis, Hoechst 33342 and PI staining (DNA binding dyes) was employed with specified concentrations of compounds $\mathbf{1}$ and 3, and $\mathbf{5}$ on MDAMB-231 and HeLa cells, respectively, for $24 \mathrm{~h}$. Selected images are shown in Fig. 7 wherein yellow, white and red arrows indicate viable, early apoptotic and late apoptotic (nuclei) cells, respectively. The live cells showed normal nuclei with blue chromatin whereas apoptotic cells showed nuclei with illuminated blue or pink chromatin that is mainly condensed or fragmented. The results also indicated that apoptotic cell death increases in a dose-dependent manner compared to the control.

\subsubsection{Apoptosis analysis by flow cytometry}

The annexin V- PI assays clearly indicated that $\mathbf{1}, \mathbf{3}$ and 5 induces apoptosis. At the $\mathrm{IC}_{50}$ concentrations of $\mathbf{1}$ and $\mathbf{3}$, the increase in early apoptotic cell population was observed from $2.24 \%$ (control) to $9.49 \%$ and $18.18 \%$, respectively, in MDAMB-231 cells. In the case of Hela cells, the increase in early apoptotic cell population was from $0.60 \%$ (control) to $9.49 \%$ at the $\mathrm{IC}_{50}$ concentration $(0.8 \mu \mathrm{M})$ and to $10.45 \%$ at $1 \mu \mathrm{M}$. The numbers of early apoptotic cells population were increased in a dosedependent manner while numbers of necrotic cell death is maximized at higher concentrations (Figs. $8 \mathrm{a}$ and $8 b)$.

Insert Figs. 8a and 8b 


\subsubsection{Cell cycle analysis}

Based on encouraging results described above, 1, 3 and 5 were further investigated in order to record changes on the cell cycle phase distribution on the basis of DNA content in MDAB-231 and HeLa cell lines after exposure for $24 \mathrm{~h}$ by flow cytometry analysis using PI staining [67]. Cells were treated with the concentrations close to the $\mathrm{IC}_{50}$ values determined for $\mathbf{1 , 3}$ and $\mathbf{5}$. According to FACS histogram statistics (Fig. 9), the compounds induce shifts in the population of cells during cell cycle as compared to the control. Treatment of MDAB-231 cells with compound 1 (at $1.0 \mu \mathrm{M}$ ) induces an increase of the percentage of the apoptotic cells in the G2/M and sub-G1 phases while a decrease in the percentage at the G1 phase of the cell cycle was noted, compared to the control. On the other hand, when the same cells were treated with 3 at concentrations of 1.0 and $1.5 \mu \mathrm{M}$, no substantial change in the cell cycle phases were noted. However, the percentage of sub-G1 phase apoptotic cells increased from ca. $0.5 \%$ to $10 \%$ and $49 \%$, respectively, compared to the control. Similarly, treatment of HeLa cells with 5 at concentrations of 0.6 and $0.8 \mu \mathrm{M}$ induced an increase in the percentage of apoptotic cells (from ca. $23 \%$ to $34 \%$ ) in the G2/M phase and a decrease (from ca. $60 \%$ to $43 \%$ ) in the $\mathrm{G} 1$ phase while a marginal increase (from ca. $1.4 \%$ to $5 \%$ ) of apoptotic cells were noted at sub-G1 phase, with respect to control. The observed data suggests an arrest of the cell cycle in the G2/M phase. Thus, histogram statistics of FACS indicated the effect of $\mathbf{1}, \mathbf{3}$ and $\mathbf{5}$ in the cell cycle phases of MDAMB-231 and HeLa cells.

\section{Insert Fig. 9}

The in vitro cytotoxicities of the triphenyltin(IV) compounds were investigated using MDAMB231 and HeLa cell lines. Results confirmed that in comparison to triphenyltin(IV) compounds (1-6), free pro-ligands $\left(\mathrm{HL}^{1}-\mathrm{HL}^{6}\right)$ showed no significant growth inhibition activities at a concentration greater than $25 \mu \mathrm{M}$ (Table 2), which signified that the chelation of the respective $\mathrm{L}^{\mathrm{n}-}$ with $\mathrm{Sn}$ was essential for anticancer potential. When the cytotoxicities of diazo compounds 1-3, with variously substituted carboxylate on the phenyl ring, is compared with their isoelectronic imino analogues 4-6, no correlations could be ascertained. However, in the present study, ortho- and para- triphenyltin(IV) carboxylate (compounds 1 and 3) functionalization at the phenyl ring with a diazo group displayed the comparable activity towards MDAMB-231 cell lines whereas meta- derivatives with imino group (compound 5) demonstrated superior activity towards HeLa cells. However, they did not show cytotoxicity towards normal cell line, HEK 293. The active compounds (1, $\mathbf{3}$ and 5) elicit apoptotic cell death in MDAMB-231 (1 and 3) and HeLa (5) cells, all in a dose-dependent fashion. Thus, it may be inferred that the apoptotic mechanisms induced by the triphenyltin(IV) compounds depends on cell type, specificity and concentrations, which is mainly prompted by apoptosis via ROS generation. 


\section{Conclusion}

In spite of several studies, the mechanisms of organotin(IV) induced apoptosis are still not fully understood and in this regard, small modular ligands with diazo- and its isoelectronic imino- scaffolds were used for the syntheses of triphenyltin(IV) carboxylates, where the carboxylate functionality was varied from ortho-, to meta- and para-positions. It was anticipated that this variation would significantly influence the nature of interaction with enzyme amino acid residues and hence, the activity of the compounds. In this pursuit, six triphenyltin(IV) esters, 1-6, have been characterized. Compounds 1 and 3 functionalized with a diazo group displayed the comparable activity towards MDAMB-231 cell lines whereas compound 5, with an imino group, demonstrated superior activity towards HeLa cells. The results indicated that the location of triphenyltin ester in ortho-, meta- and para-positions of the ligand does exert a meaningful influence on the cytotoxicity. The tested compounds did not show any adverse cytotoxicity towards normal cell line, HEK 293, making them suitable candidates for drug development. The present study provides novel insight into the mechanism of cytotoxicity for new triphenyltin(IV) compounds. On the basis of the performances of 1-6, further studies were carried out using compounds $\mathbf{1}$, 3 and 5. They were subjected to induce oxidative stress, which leads to apoptotic cell death as revealed from ROS measurement by DCFH-DA and Hoechst 33342/PI staining, respectively. Thus, compounds exert their antitumor effect by elevating intracellular ROS generation, independent of the cell line. Compound 5 was found to be the most potent compound, exhibiting very high cytotoxic activity (31-fold) compared to CDDP, importantly without affecting normal cells. The results suggest that $\mathbf{5}$ merits further investigation as a new potential therapeutic candidate for cancer treatment and may be a suitable candidate for modification in order to improve cytotoxic and dissolution properties. Further work in this area is underway.

$\begin{array}{ll}\text { Abbreviations } \\ \text { ROS } & \begin{array}{l}\text { reactive oxygen species } \\ \text { compound concentrations that produce 50\% of cell growth inhibition }\end{array} \\ \text { IC }_{50} & \text { 3-(4,5-dimethylthiazol-2-yl)-2,5-diphenyltetrazolium bromide } \\ \text { MTT } & \text { dichlorodihydrofluorescein diacetate } \\ \text { DCFH-DA } & \text { propidium iodide } \\ \text { PI } & \text { cisplatin, cis-diammine-dichloroplatinum(II) } \\ \text { CDDP } & \text { fluorescence-activated cell sorting } \\ \text { FACS } & \text { Dulbecco's modified eagle medium } \\ \text { DMEM } & \text { fetal bovine serum } \\ \text { FBS } & \text { Oak Ridge thermal ellipsoid plot program (molecular modeling) } \\ \text { ORTEP } & \text { phosphate-buffered saline } \\ \text { PBS } & \text { 2,7-dichlorodihydrofluorescein } \\ \text { DCFH } & \text { 2,7-dichlorofluorescein }\end{array}$




\section{Acknowledgements}

The financial support of the Council of Scientific and Industrial Research, New Delhi (Grant No. 01(2734)/13/EMR-II, 2013, TSBB) and the University Grants Commission, New Delhi, India, through SAP-CAS, Phase-I is gratefully acknowledged. Authors (TSBB, DD) acknowledge DST-PURSE for the diffractometer facility. The authors (RP, NKR, BK) acknowledge financial support through UGC-CAS Phase-IV and Interdisciplinary School of Life Sciences (ISLS), Institute of Science, Banaras Hindu University, for providing flow cytometry facility.

\section{Conflict of interests}

The authors declare that they have no conflicts of interest with the contents of this article.

\section{Appendix A. Supplementary data}

Crystallographic data for compounds $\mathrm{HL}^{4}, \mathbf{2}$ and $\mathbf{5}$ reported in this paper have been deposited with the Cambridge Crystallographic Data Centre (CCDC) as supplementary publication nos. 1489688-1489690. These data can be obtained free of charge via www.ccdc.cam.ac.uk/getstructures.

The following information (Figs. S1-S6) are available as Supplementary Materials. Fig S1: Uv-Vis absorption spectra over time for triphenyltin(IV) compounds 1-6 in DMSO. Fig. S2: Molecular packing in HL $^{4}$ : (a) view of the supramolecular chain along $\left[\begin{array}{lll}1 & 1 & 1\end{array}\right]$ mediated by aryl-C-H...O(carbonyl) interactions, shown as orange dashed lines, (b) view of the supramolecular tube sustained by methyl-C-H... $(\operatorname{aryl})$ interactions shown as purple dashed lines and (c) view in projection down the $c$-axis of the unit cell contents. Intermolecular contacts: $\mathrm{C} 11-\mathrm{H} 11 \ldots \mathrm{O} 2^{\mathrm{i}}=2.35 \AA, \mathrm{C} 11 \ldots \mathrm{O} 2^{\mathrm{i}}=3.212(3) \AA$ with angle at $\mathrm{H} 11=$ $153^{\circ} . \mathrm{C} 15-\mathrm{H} 15 \mathrm{a} \ldots \mathrm{Cg}(\mathrm{C} 1-\mathrm{C} 6)^{\mathrm{ii}}=2.93 \AA, \mathrm{C} 15 \ldots \mathrm{Cg}(\mathrm{C} 1-\mathrm{C} 6)^{\mathrm{ii}}=3.750(3) \AA$ with angle at $\mathrm{H} 15 \mathrm{a}=143^{\circ}$. Symmetry operations: $i,-1 / 2+x,-1 / 2+y,-1 / 2+z ; i i, 1-x, 1-y, 1-z$; Fig S3: View in projection down the $a$-axis of the unit cell contents of 2 . Intermolecular contacts: $\pi(\mathrm{C} 1-\mathrm{C} 6) \ldots \pi(\mathrm{C} 8-\mathrm{C} 13)^{\mathrm{i}}, \mathrm{Cg} \ldots \mathrm{Cg}=3.6664(15) \AA$ for dihedral angle $7.21(13)^{\circ}$, shown as blue dashed lines. $\mathrm{C} 24-\mathrm{H} 24 \ldots \mathrm{Cg}(\mathrm{C} 31-\mathrm{C} 36)^{\mathrm{ii}}=2.88 \AA$, $\mathrm{C} 24 \ldots \mathrm{Cg}(\mathrm{C} 31-\mathrm{C} 36)^{\mathrm{ii}}=3.793(4) \AA$ with angle at $\mathrm{H} 24=167^{\circ} . \quad \mathrm{C} 35-\mathrm{H} 35 \ldots \mathrm{Cg}(\mathrm{C} 41-\mathrm{C} 46)^{\mathrm{i}}=2.88 \AA$, $\mathrm{C} 35 \ldots \mathrm{Cg}(\mathrm{C} 41-\mathrm{C} 46)^{\mathrm{i}}=3.623(4) \AA$ with angle at $\mathrm{H} 35=137^{\circ} . \mathrm{C}-\mathrm{H} \ldots \pi$ contacts are shown as purple dashed lines. Symmetry operations: $i, 1+x, y, z ; i i, x, 1 / 2-y,-1 / 2+z$; Fig. S4: View in projection down the $a$ - 
axis of the unit cell contents of 5. Intermolecular contacts: $\mathrm{C} 24-\mathrm{H} 24 \ldots \mathrm{O} 2^{\mathrm{i}}=2.57 \AA, \mathrm{C} 24 \ldots \mathrm{O} 2^{\mathrm{i}}=3.307(5)$ $\AA$ with angle at $\mathrm{H} 24=137^{\circ}$, shown as orange dashed lines. $\mathrm{C} 15-\mathrm{H} 15 \mathrm{~B} \ldots \mathrm{Cg}(\mathrm{C} 1-\mathrm{C} 6)^{\mathrm{ii}}=2.91 \AA$, $\mathrm{C} 15 \ldots \mathrm{Cg}(\mathrm{C} 1-\mathrm{C} 6)^{\mathrm{ii}}=3.781(6) \AA$ with angle at $\mathrm{H} 15 \mathrm{~B}=151^{\circ} . \quad \mathrm{C} 44-\mathrm{H} 44 \ldots \mathrm{Cg}(\mathrm{C} 9-\mathrm{C} 14)^{\mathrm{iii}}=2.92 \AA$, $\mathrm{C} 44 \ldots \mathrm{Cg}(\mathrm{C} 9-\mathrm{C} 14)^{\mathrm{iii}}=3.546(4) \AA$ with angle at $\mathrm{H} 44=125^{\circ} . \mathrm{C} 45-\mathrm{H} 45 \ldots \mathrm{Cg}(\mathrm{C} 31-\mathrm{C} 36)^{\mathrm{iv}}=2.99 \AA$, $\mathrm{C} 45 \ldots \mathrm{Cg}(\mathrm{C} 31-\mathrm{C} 36)^{\mathrm{iv}}=3.670(5) \AA$ with angle at $\mathrm{H} 45=132^{\circ} . \mathrm{C}-\mathrm{H} \ldots \pi$ contacts are shown as purple dashed lines. Symmetry operations: $i, 1-x,-1 / 2+y, 1 \frac{1}{2}-z ; i i, 1+x, y, z ; i i i,-1+x, 1 / 2-y,-1 / 2+z ; i v,-x, 1 / 2+y, 1 \frac{1}{2}-$ $z$; Fig. S5: Dose dependent cytotoxic effects (a) Bar and (b) Graphical representations of compounds 1, 3 and 5 on HEK 293 cells by MTT assay after incubation with various concentrations of compounds for 24 h. Bars represent \pm SEM ( $=3)$. Fig. S6: Generations of ROS induced by $\mathbf{1}$ and $\mathbf{3}$ in MDAMB-231 and $\mathbf{5}$ in Hela cells viewed through fluorescence microscope, when treated with $\mathrm{IC}_{50}$ concentrations of the respective compounds (see Table 2). 


\section{References}

[1] B. Lippert (Ed.), Cisplatin- Chemistry and Biochemistry of a Leading Anticancer Drug, Wiley, Weinheim, Germany, 1999.

[2] A. Bonetti, R. Leone, F. Muggia, S.B. Howell (Ed.), Platinum and Other Heavy Metal Compounds in Cancer Chemotherapy: Molecular Mechanism and Clinical Applications, Humana Press, New York, USA, 2009.

[3] A. Florea, D. Büsselberg, Cancers 3 (2011) 1351-1371.

[4] S. Dasari, P.B. Tchounwou, Eur. J. Pharmacol. 740 (2014) 364-378.

[5] K.D. Mjos, C. Orvig, Chem. Rev. 114 (2014) 4540-4563.

[6] W.A. Wani, S. Prashar, S. Shreaz, S. Gómez-Ruiz, Coord. Chem. Rev. 312 (2016) 67-98.

[7] Z. Liu, P.J. Sadler, Acc. Chem. Res. 47 (2014) 1174-1185.

[8] M. Dörr, E. Meggers, Curr. Opin. Chem. Biol. 19 (2014) 76-81.

[9] C.-M. Che, R.W.-Y. Sun, Chem. Commun. 47 (2011) 9554-9560.

[10] A.C. Komor, J.K. Barton, Chem. Commun. 49 (2013) 3617-3630.

[11] J. Kljun, I. Bratsos, E. Alessio, G. Psomas, U. Repnik, M. Butinar, B. Turk, I. Turel, Inorg. Chem. 52 (2013) 9039-9052.

[12] G. Gasser, I. Ott, N. Metzler-Nolte, J. Med. Chem. 54 (2011) 3-25.

[13] C.M. Clavel, E. Paunescu, P. Nowak-Sliwinska, P.J. Dyson, Chem. Sci. 5 (2014) 1097-1101.

[14] C.G. Hartinger, N. Metzler-Nolte, P.J. Dyson, Organometallics 31 (2012) 5677-5685.

[15] G. Sava, A. Bergamo, P.J. Dyson, Dalton Trans. 40 (2011) 9069-9075.

[16] Y. Geldmacher, M. Oleszak, W.S. Sheldrick, Inorg. Chim. Acta 393 (2012) 84-102.

[17] B. Kupcewicz, K. Sobiesiak, K. Malinowska, K. Koprowska, M. Czyz, B. Keppler, E. Budzisz, Med. Chem. Res. 22 (2013) 2395-2402. 
[18] M. Groessl, C.G. Hartinger, Anal. Bioanal. Chem. 405 (2013) 1791-1808.

[19] C.J. Marmion, D.M. Griffith, J. Parker, Z. Ude, H. Nimir, M. Morgan, M. Brennan, B. Duff, D. Egan, A. Chubb, J. Kasparkova, V. Brabec, J. Biol. Inorg. Chem. 19 (2014) S463.

[20] G. Gasser, N. Metzler-Nolte, Curr. Opin. Chem. Biol. 16 (2012) 84-91.

[21] A. Levina, A. Mitra, P.A. Lay, Metallomics 1 (2009) 458-470.

[22] Y. Chen, M.Y. Qin, J.H. Wu, L. Wang, H. Chao, L.N. Ji, A.L. Xu, Eur. J. Med. Chem. 70 (2013) 120129.

[23] L.Y. Li, K.J. Du, Y. Wang, H.N. Jia, X.J. Hou, H. Chao, L.N. Ji, Dalton Trans. 42 (2013) 1157611588.

[24] A.G. Davies, M. Gielen, K.H. Pannell, E.R.T. Tiekink (Ed.), Tin Chemistry Fundamentals, Frontiers and Application, Wiley, Chichester, UK, 2008.

[25] S.K. Hadjikakou, N. Hadjiliadis, Coord. Chem. Rev. 253 (2008) 235-249.

[26] C.E. Carraher Jr., M.R. Roner, J. Organomet. Chem. 751 (2014) 67-82.

[27] F. Arjmand, S. Parveen, S. Tabassum, C. Pettinari, Inorg. Chim. Acta 423 (2014) 26-37.

[28] L. Niu, Y. Li, Q. Li, Inorg. Chim. Acta 423 (2014) 2-13.

[29] M.K. Amir, S. Khan, Z.-ur-Rehman, A. Shah, I.S. Butler, Inorg. Chim. Acta 423 (2014) 14-25.

[30] M.Z. Bulatović, D. Maksimović-Ivanić, C. Bensing, S. Gómez-Ruiz, D. Steinborn, H. Schmidt, M. Mojić, A. Korać, I. Golić, D. Pérez-Quintanilla, M. Momčilović, S. Mijatović, G.N. Kaluđerović, Angew. Chem. Int. Ed. 53 (2014) 5982-5987.

[31] Y. Cao, R.A. DePinho, M. Ernst, K. Vousden, Nat. Rev. Cancer 11 (2011) 749-754.

[32] E.S.F. Ma, W.D. Bates, A. Edmunds, L.R. Kelland, T. Fojo, N. Farrell, J. Med. Chem. 48 (2005) $5651-5654$.

[33] A.G. Quiroga, J.M. Pérez, C. Alonso, C. Navarro-Ranninger, N. Farrell, J. Med. Chem. 49 (2005) 224231.

[34] D. Pérez-Quintanilla, S. Gómez-Ruiz, Ž. Žižak, I. Sierra, S. Prashar, I. del Hierro, M. Fajardo, Z.D. 
Juranić, G.N. Kaluđerović, Chem. Eur. J., 15 (2009) 5588-5597.

[35] G.N. Kaluđerović, H. Kommera, E. Hey-Hawkins, R. Paschke, S. Gómez-Ruiz, Metallomics, 2 (2010) 419-428.

[36] S. Gómez-Ruiz, G.N. Kaluđerović, S. Prashar, E. Hey-Hawkins, A. Erić, Ž. Žižak, Z.D. Juranić, J. Inorg. Biochem. 102 (2008) 2087-2096.

[37] S.M. Aris, D.A. Gewirtz, J.J. Ryan, K.M. Knott, N.P. Farrell, Biochem. Pharmacol. 73 (2007) 17491757.

[38] G.H. Bulluss, K.M. Knott, E.S.F. Ma, S.M. Aris, E. Alvarado, N. Farrell, Inorg. Chem. 2006, 45, $5733-5735$.

[39] T.S. Basu Baul, D. Dutta, A. Duthie, M.F.C. Guedes da Silva, Inorg. Chim. Acta, 2016, 455 (2017) 627-637.

[40] F.P. Pruchnik, M.Bańbuła, Z. Ciunik, H. Chojnacki, M. Latocha, B. Skop, T. Wilczok, A. Opolski, J. Wietrzyk, A. Nasulewicz, Eur. J. Inorg. Chem. 12 (2002) 3214-3221.

[41] Agilent Technologies, CrysAlisPro. Santa Clara, CA, USA. 2013.

[42] G.M. Sheldrick, Acta Crystallogr. Sect. A, Foundat. Crystallogr. 64 (2008) 112-122.

[43] G.M. Sheldrick, Acta Crystallogr. Sect. C, Struct. Chem. 71 (2015) 3-8.

[44] L.J. Farrugia, J. Appl. Crystallogr. 45 (2012) 849-854.

[45] DIAMOND, Visual crystal structure information system, Version 3.1, CRYSTAL IMPACT, Postfach 1251, D-53002 Bonn, Germany, 2006.

[46] A.L. Spek, Acta Crystallogr. Sect. D, Biol. Crystallogr. 65 (2009) 148-155.

[47] T.J. Mosmann, J. Immunol. Methods 65 (1983) 55-63.

[48] E. Corral, A.C.G. Hotze, H. den Dulk, A. Leczkowska, A. Rodge, M.J. Hanno, J. Reedijk, J. Biol. Inorg. Chem. 14 (2009) 439-448.

[49] T.S. Basu Baul, A. Paul, L. Pellerito, M. Scopelliti, P. Singh, P. Verma, D. de Vos, Invest. New Drugs 28 (2010) 587-599. 
[50] M. Nath, P.K. Saini, Dalton Trans. 40 (2011) 7077-7121.

[51] G.B. Deacon, R.J. Phillips, Coord. Chem. Rev. 33 (1980) 227-250.

[51] D. Martinez, M. Motevalli, M. Watkinson, Dalton Trans. 39 (2010) 446-455.

[53] J. Holeček, M. Nádvorník, K. Handliř, A. Lyčka, J. Organomet. Chem. 241 (1983) 177-184.

[54] R. Willem, I. Verbruggen, M. Gielen, M. Biesemans, B. Mahieu, T.S. Basu Baul, E.R.T. Tiekink, Organometallics 17 (1998) 5758-5766.

[55] J.B. Benedict, D.E. Cohen, S. Lovell, A.L. Rohl, B. Kahr, J. Am. Chem. Soc. 128 (2006) 5548-5559.

[56] F.P. Pruchnik, M. Bańbuła, Z. Ciunik, M. Latocha, B. Skop, T. Wilczok, Inorg. Chim. Acta 356 (2003) 62-68.

[57] E.R.T. Tiekink, Appl. Organometal. Chem. 5 (1991) 1-23.

[58] A. Růžička, A. Lyčka, R. Jambor, P. Novák, I. Čisařová, M. Holčapek, M. Erben, J. Holeček, Appl. Organometal. Chem. 17 (2003) 168-174.

[59] T.S. Basu Baul, E.R.T. Tiekink, J. Chem. Crystallogr. 26 (1996) 393-397.

[60] Y. Zhang, S. Choksi, K. Chen, Y. Pobezinskaya, I. Linnoila, Z.-G. Liu, Cell Research, 23 (2013) 898914.

[61] G.-Y. Liou, P. Storz, Free Radic. Res., 2010 May, 44(5), 10.3109/10715761003667554.

[62] Ž. Jakšić, in: A. Pagliarani, F. Trombetti, V. Ventrella (Ed.), Biochemical and Biological Effects of Organotins, Bentham Science Publishers, 2012.

[63] H. Wang, J.A. Joseph, Free Radical Biol. Med. 27 (1999) 612-616.

[64] A. Gomes, E. Fernandes, J.L.F.C. Lima, J. Biochem. Biophys. Methods 65 (2005) 45-80. 
[65] S. Kasibhatla, B. Tseng, Mol. Cancer Ther. 2 (2003) 573-580.

[66] J.F. Kerr, Toxicol. 181-182 (2002) 471-474.

[67] C.C. Chou, J.S. Yang, H.S. Lu, S.W. Ip, C. Lo, C.C. Wu, J.P. Lin, N.Y. Tang, J.G. Chung, M.J. Chou, Y.H. Teng, D.R. Chen, Arch. Pharm. Res. 33 (2010) 1181-1191. 


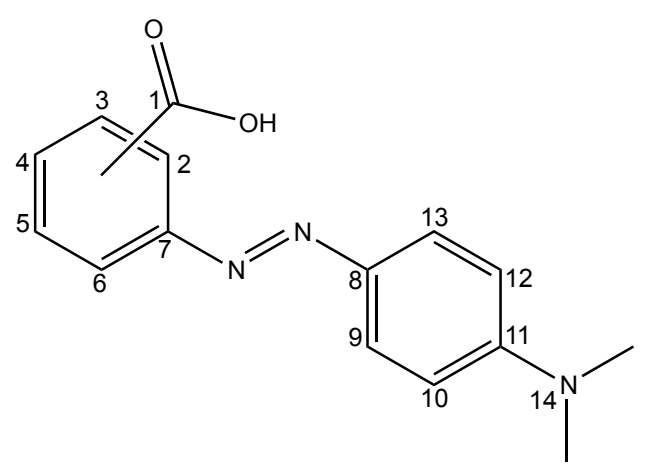

2-CO ${ }_{2} \mathrm{H}: \mathrm{L}^{1} \mathrm{H}, 3-\mathrm{CO}_{2} \mathrm{H}: \mathrm{L}^{2} \mathrm{H}, 4-\mathrm{CO}_{2} \mathrm{H}: \mathrm{L}^{3} \mathrm{H}$

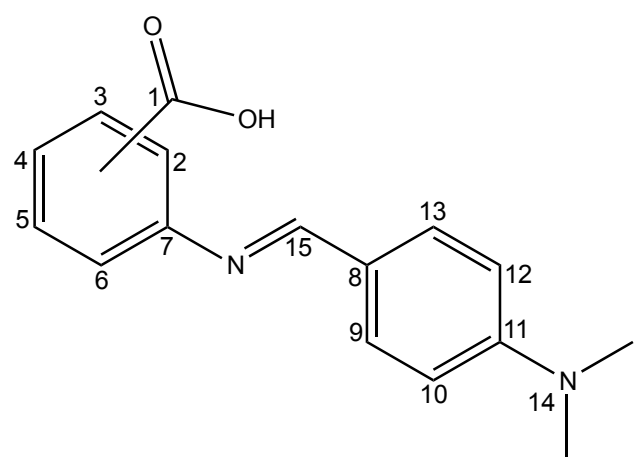

2- $\mathrm{CO}_{2} \mathrm{H}: \mathrm{L}^{4} \mathrm{H}, 3-\mathrm{CO}_{2} \mathrm{H}: \mathrm{L}^{5} \mathrm{H}, 4-\mathrm{CO}_{2} \mathrm{H}: \mathrm{L}^{6} \mathrm{H}$

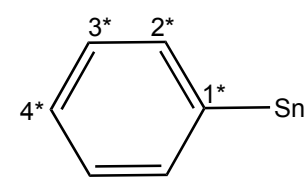

Sn-Ph

Fig. 1 Generic structures with numbering protocol of pro-ligands $\mathrm{HL}^{\mathrm{n}}(\mathrm{n}=1-6)$ and tin phenyl moiety.

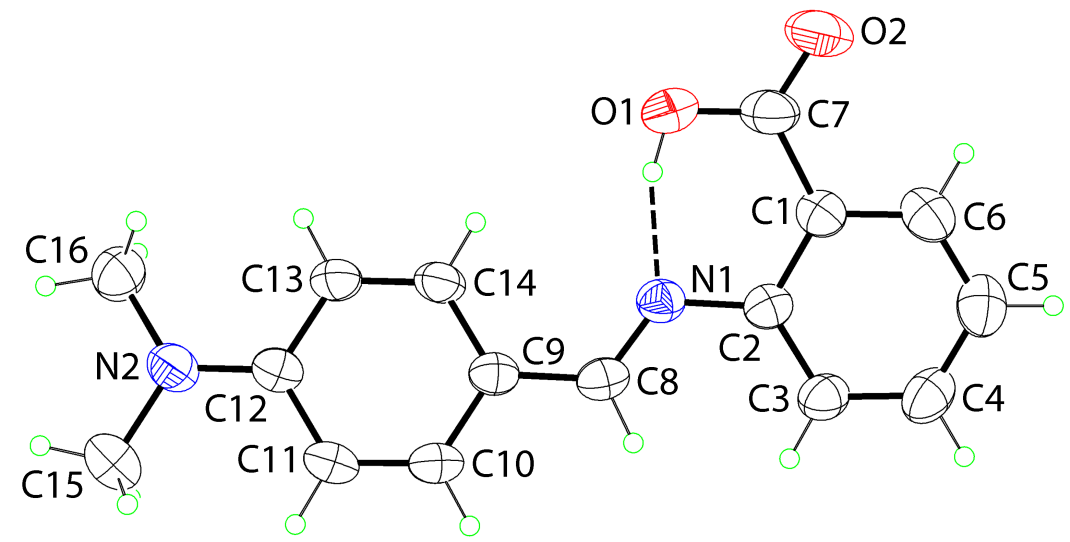

Fig. 2 Perspective view of the molecular structure of $\mathrm{HL}^{4}$. Selected geometric parameters: C7-O1 1.311(3), C7-O2 1.214(3), C8-N1 1.283(2) Å, O1-C7-O2 121.4(2), C2-N1-C8 123.31(18), N1-C8-C9 123.98(19) . Intramolecular hydrogen bond: O1-H1o... N = 1.71(2) $\AA, \mathrm{O} 1 \ldots \mathrm{N} 1=2.504(2) \AA$ with an angle of $157(3)^{\mathrm{o}}$ subtended at H1o. 


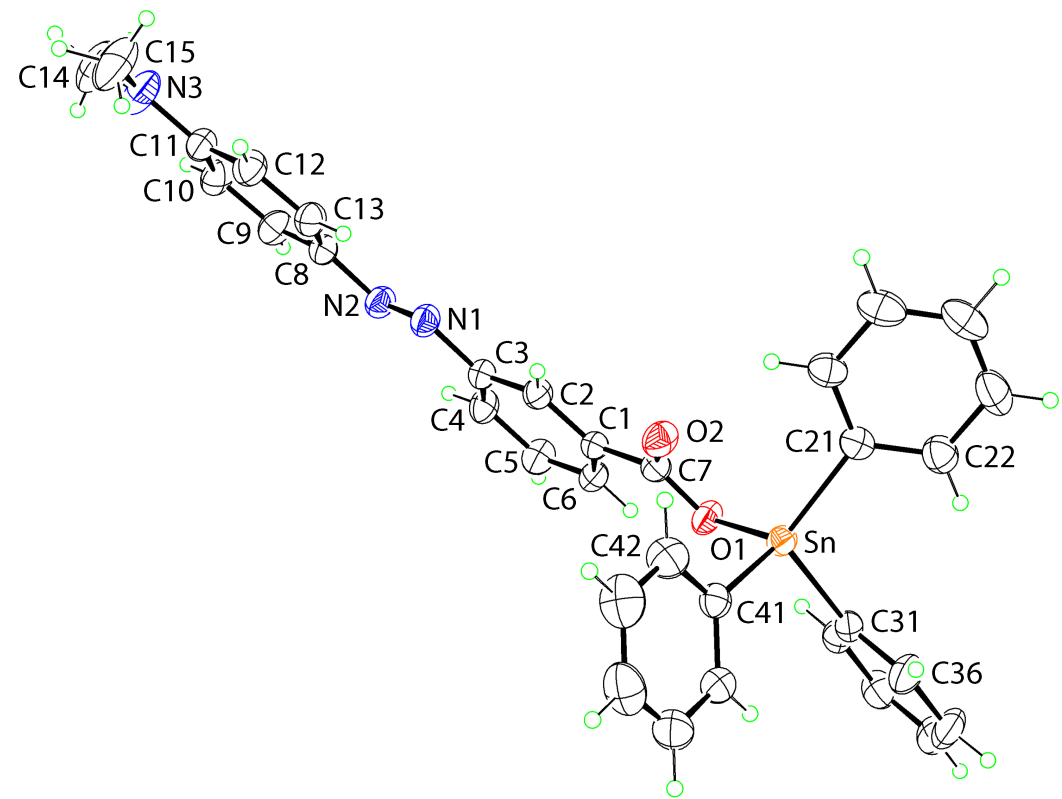

Fig. 3 Perspective view of the molecular structure of 2. Selected geometric parameters: $\mathrm{Sn}-$ O1 2.0705(18), C7-O1 1.307(3), C7-O2 1.234(3), N1-N2 1.254(3) A.

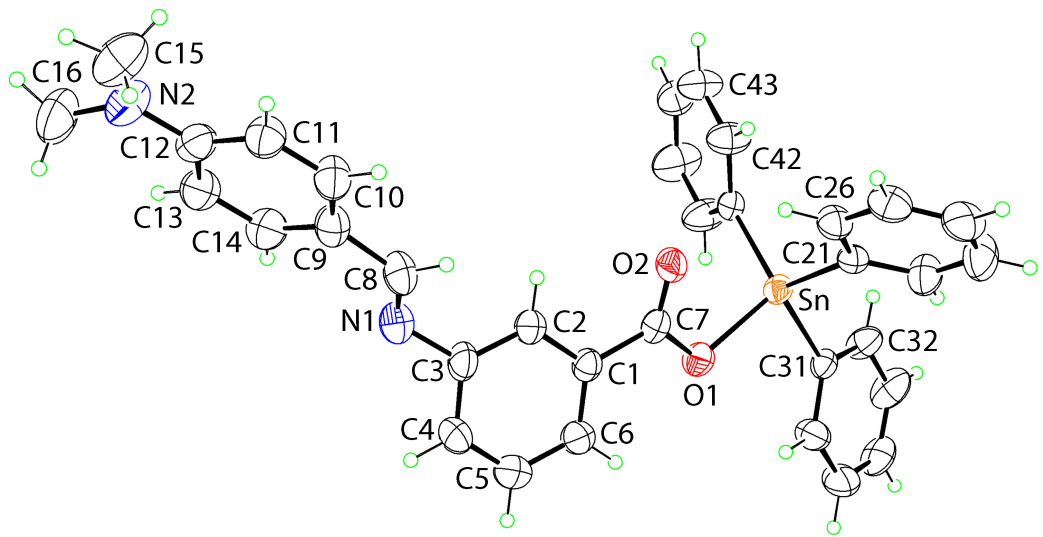

Fig. 4 Perspective view of the molecular structure of 5. Selected geometric parameters: SnO1 2.068(2), C7-O1 1.311(3), C7-O2 1.224(3), C8-N1 1.244(5) A.. 

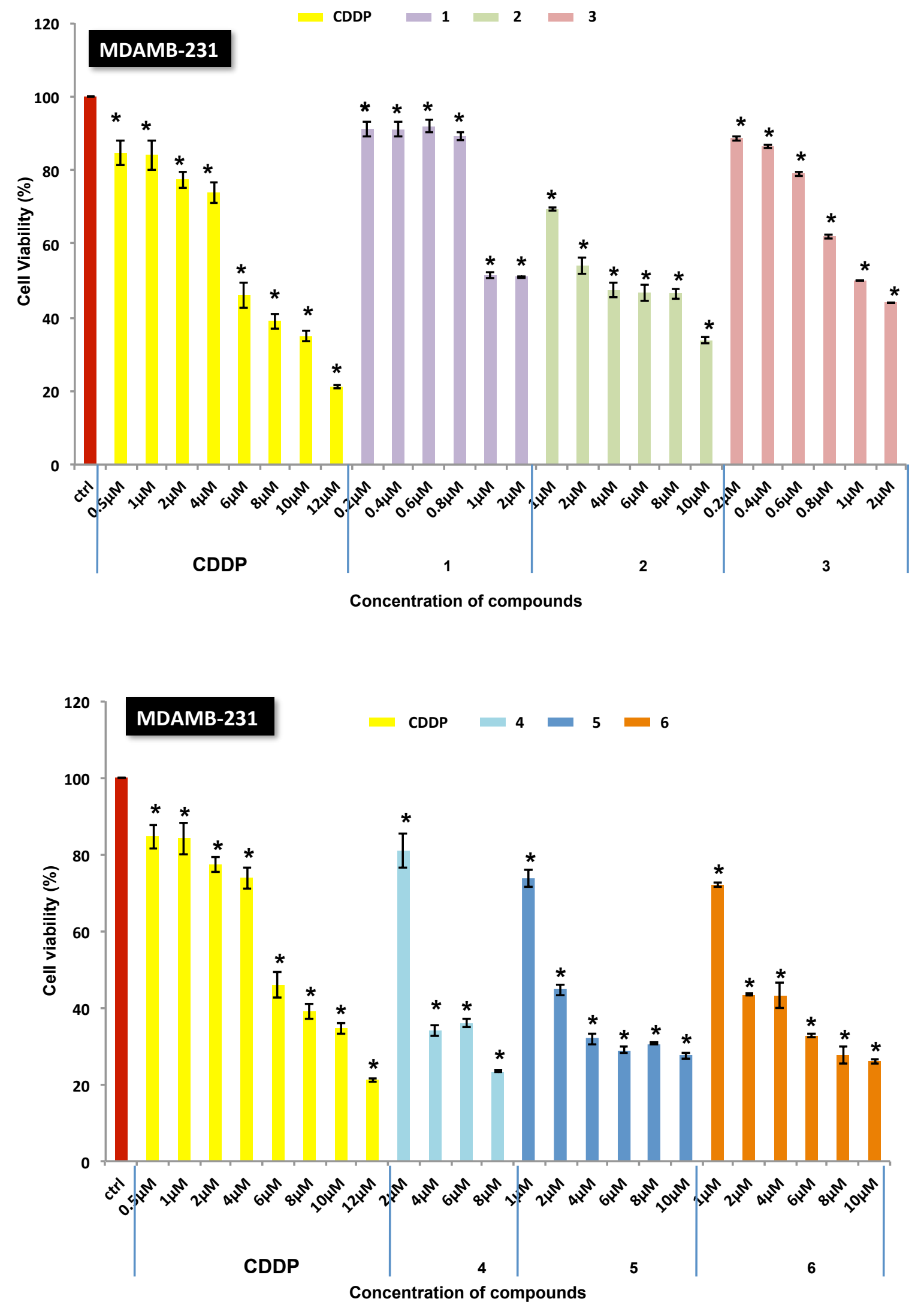

(a) 

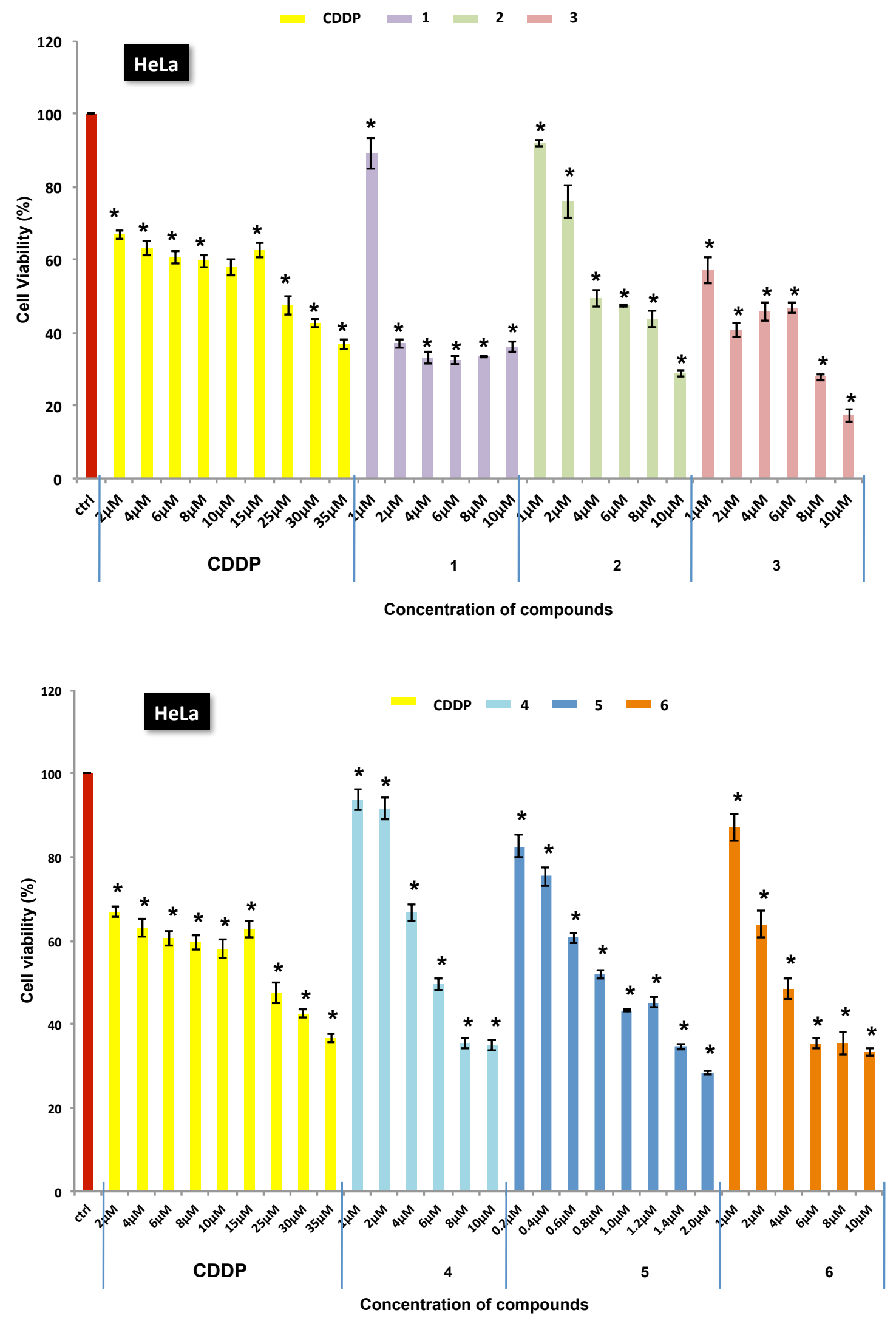

(b) 
Fig. 5. Dose dependent cytotoxic effects of compounds 1-6 on (a) MDAMB-231 and (b) HeLa cells by MTT assay after incubation with various concentrations of compounds for $24 \mathrm{~h}$. Bars represent $\pm \operatorname{SEM}(n=3)$. Statistical analysis has been done by one way ANOVA followed by Tukey test where $*$ denotes significant difference $(\mathrm{P}<0.05)$ as compared to control. 


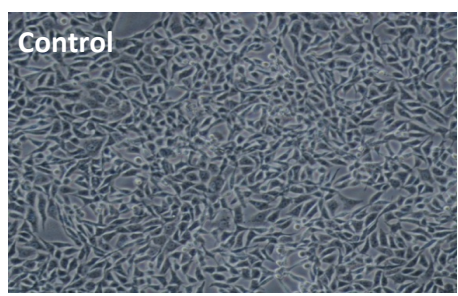

Control
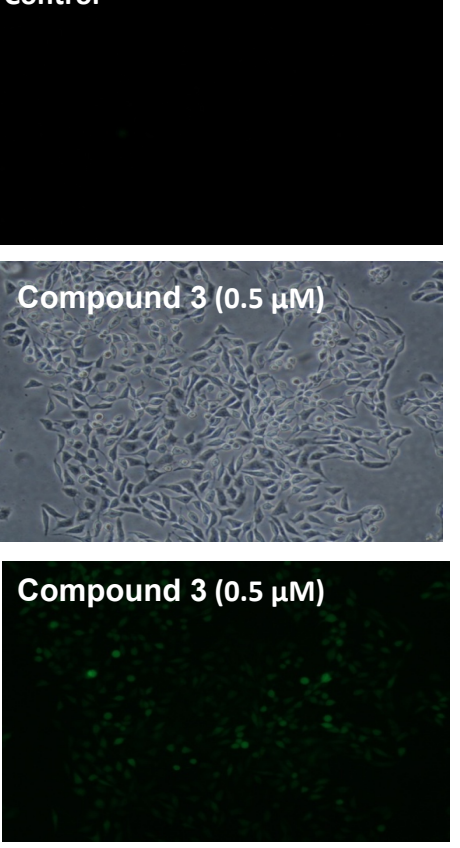

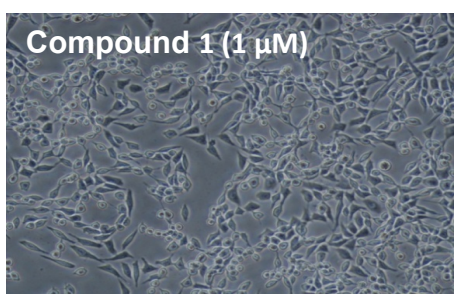

Compound 1 (1 $\mu \mathrm{M})$
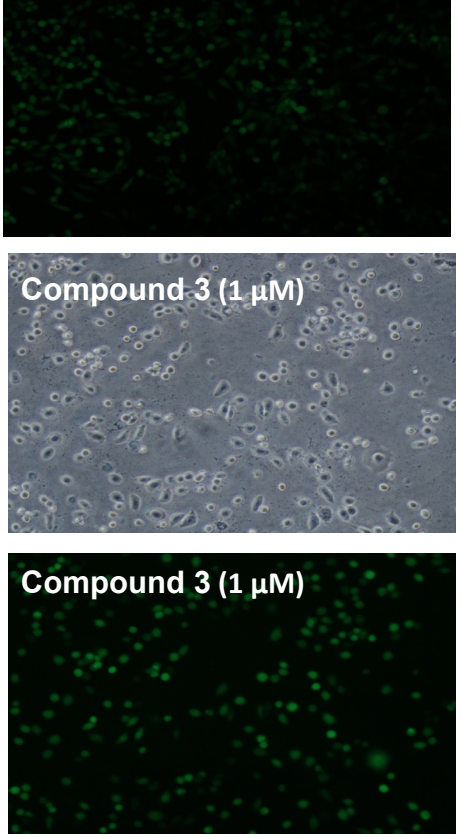

(a)
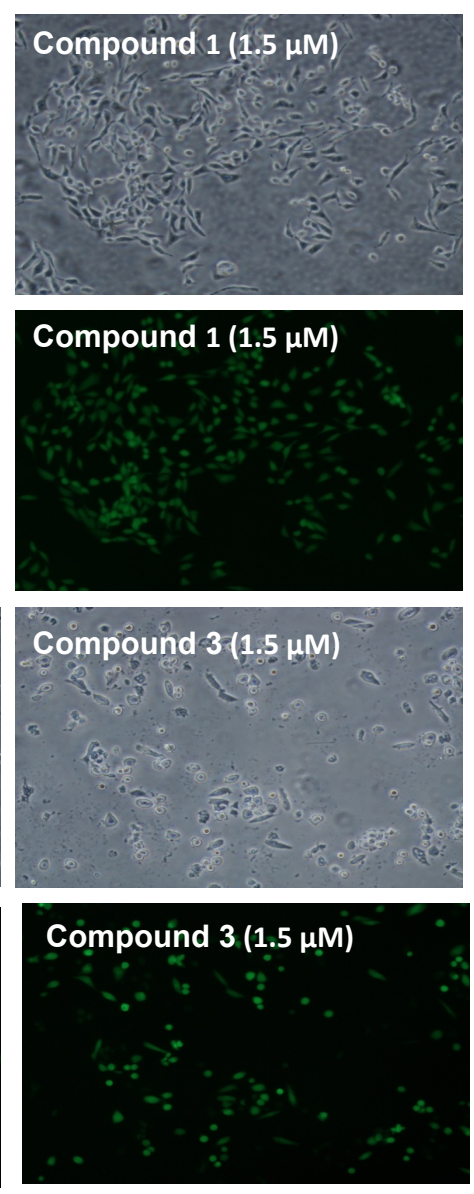

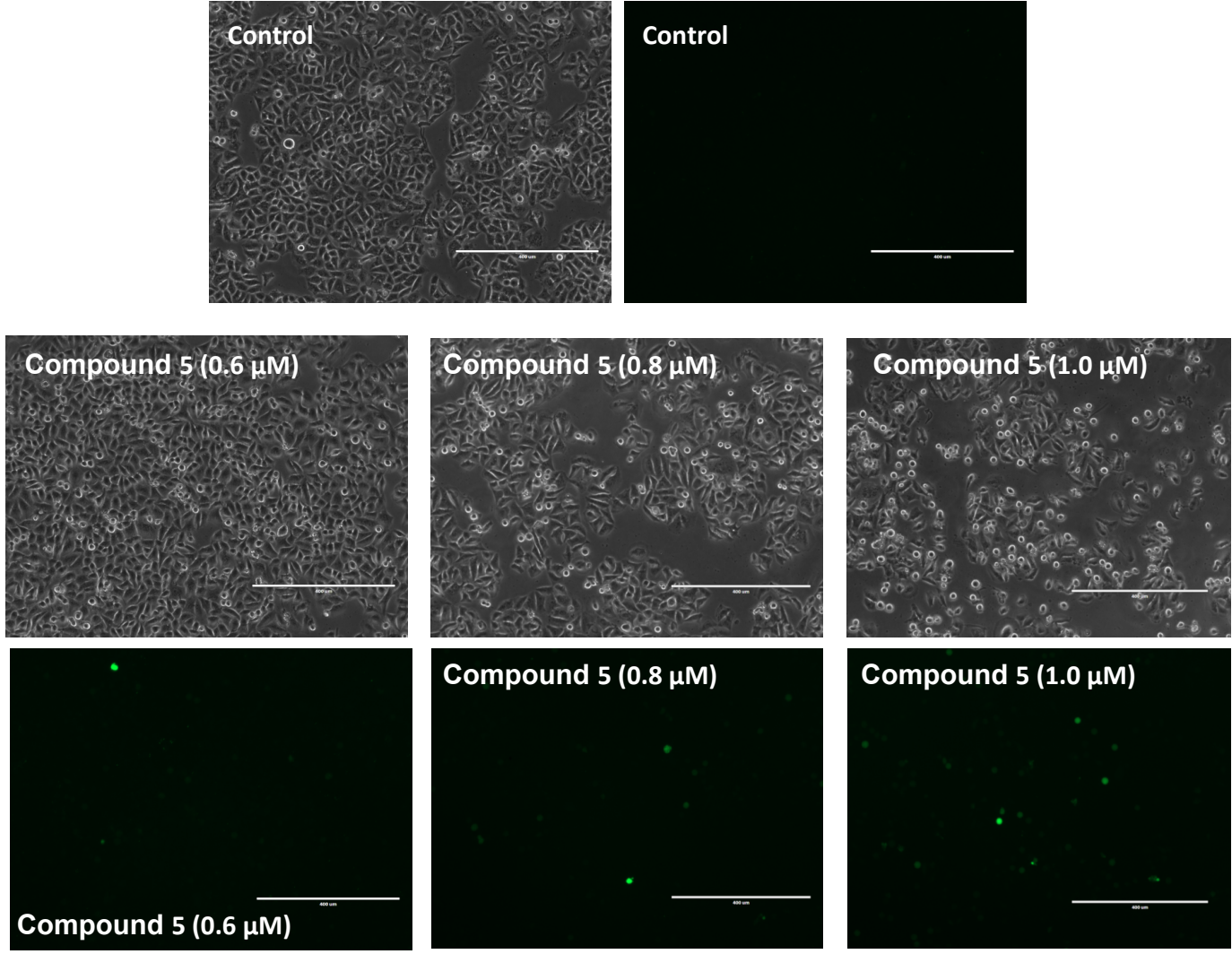

(b)

Fig. 6 Dose-dependent generations of $\mathrm{ROS}$ when treated with $\mathrm{IC}_{50}$ concentrations of the respective compounds induced by (a) $\mathbf{1}$ and $\mathbf{3}$ in MDAMB-231 and (b) $\mathbf{5}$ in Hela cells detected by measuring the fluorescence intensity using DCFH-DA viewed through fluorescence microscope. 


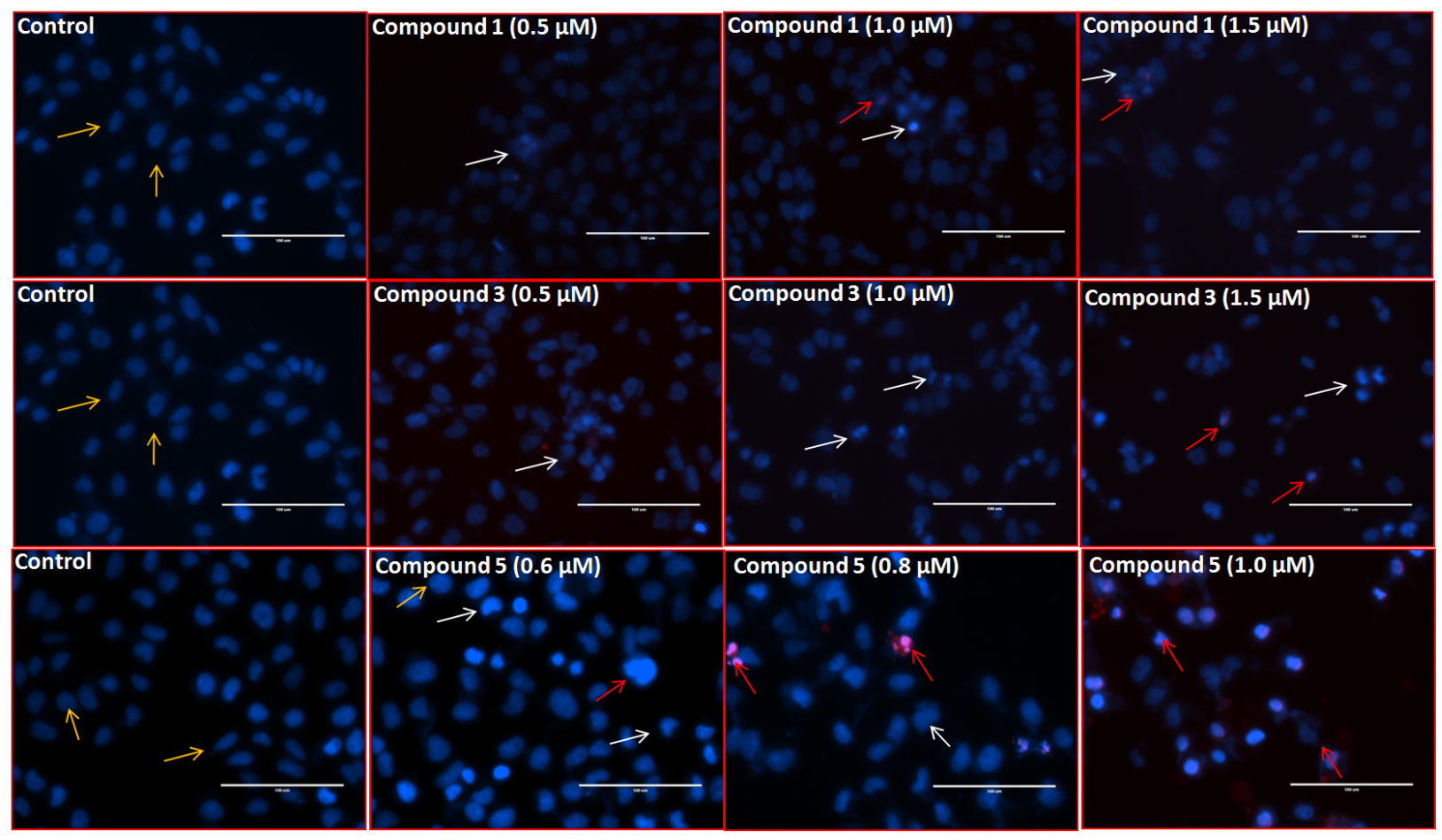

Fig. 7 Fluorescence microscope images showing morphological (nuclear) changes in MDAMB-231 and HeLa cells upon treatment with specified concentrations of compounds (1 and $\mathbf{3})$ and (5), respectively, by dual staining with Hoechst 33342 and PI for 24 h. Yellow arrows represents live cell nuclei, white arrows show bright blue condensed apoptotic nuclei whereas red arrows show pink fragment apoptotic nuclei. 


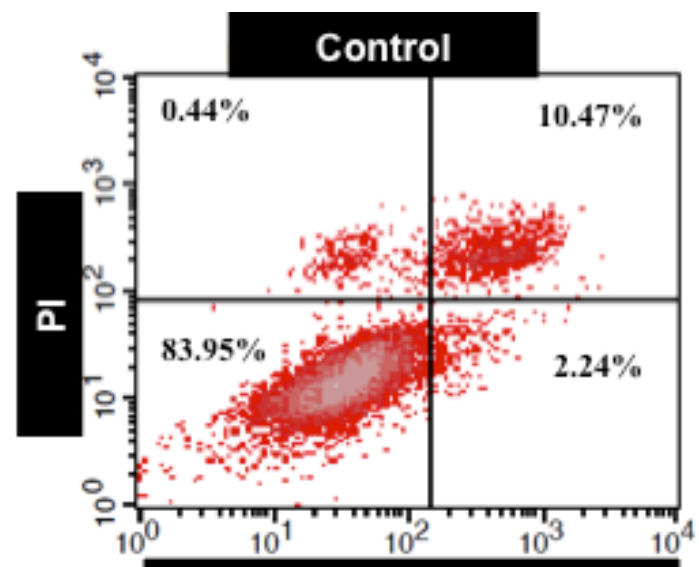

UL- Necrotic

UR- Late apoptotic

LL- Live cells

LR- Early apoptotic

Annexin V - Alexa Fluor 488

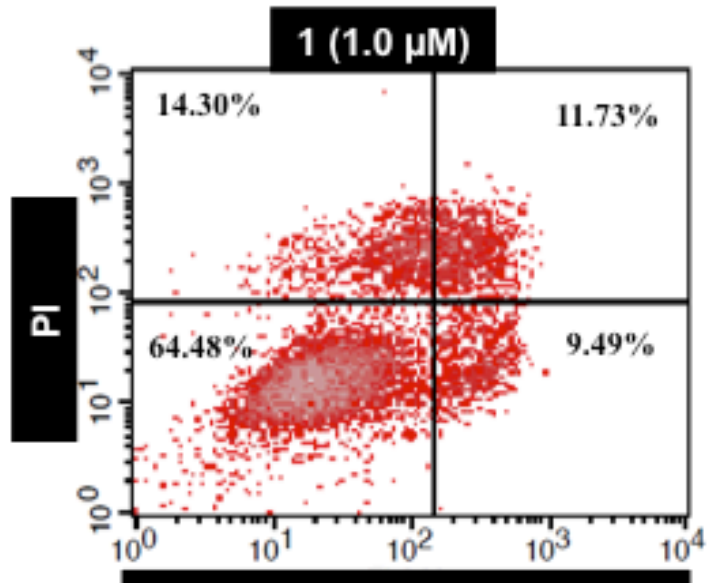

Annexin V - Alexa Fluor 488

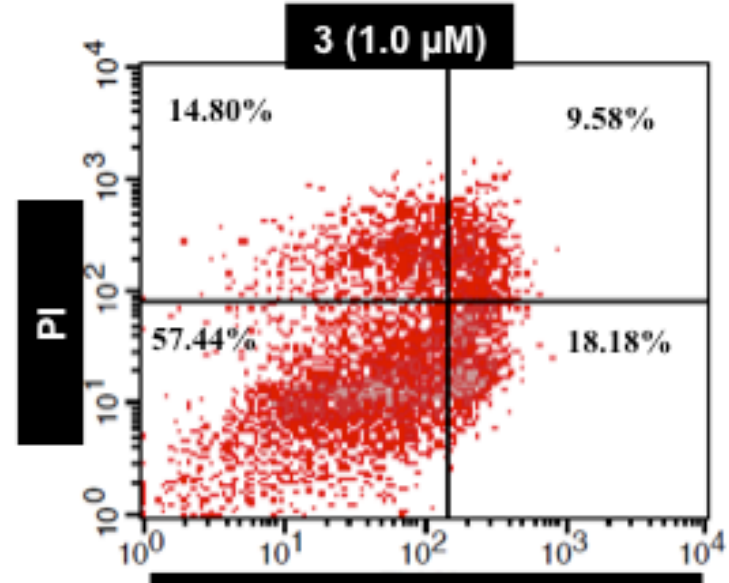

Annexin V - Alexa Fluor 488

(a) 

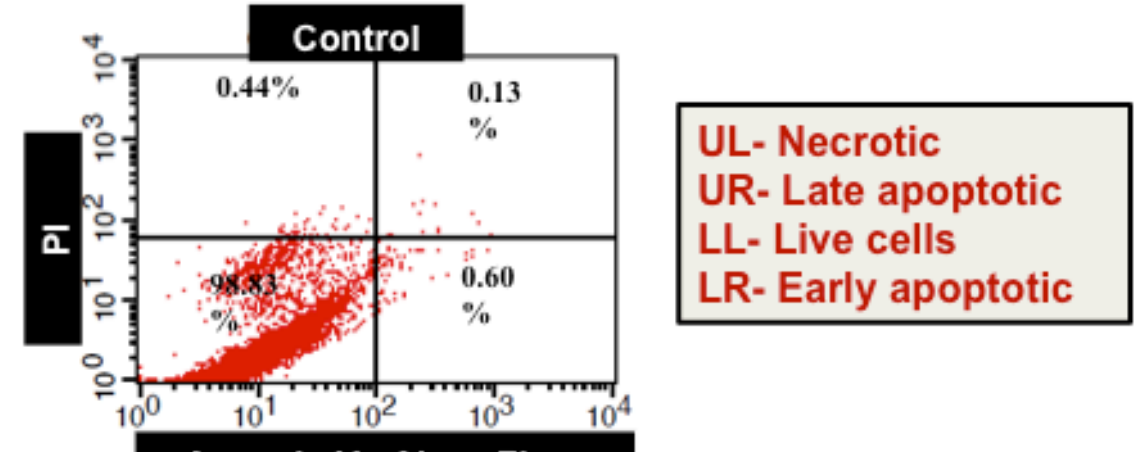

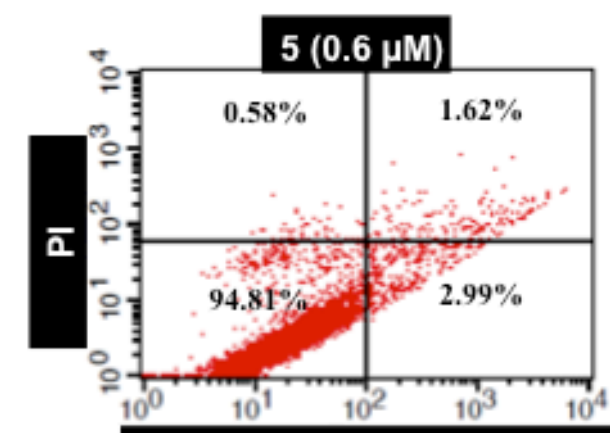

Annexin V - Alexa Fluor

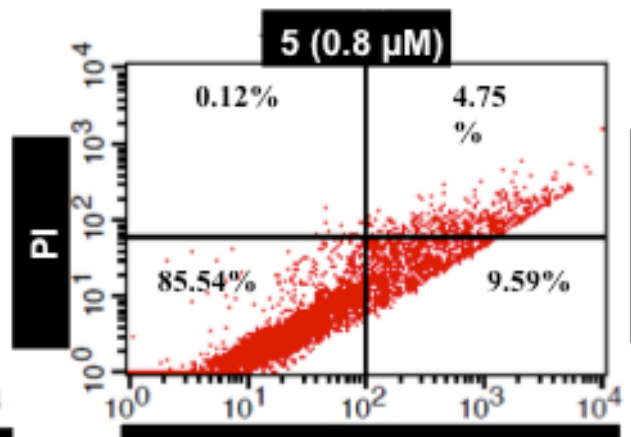

Annexin V - Alexa Fluor

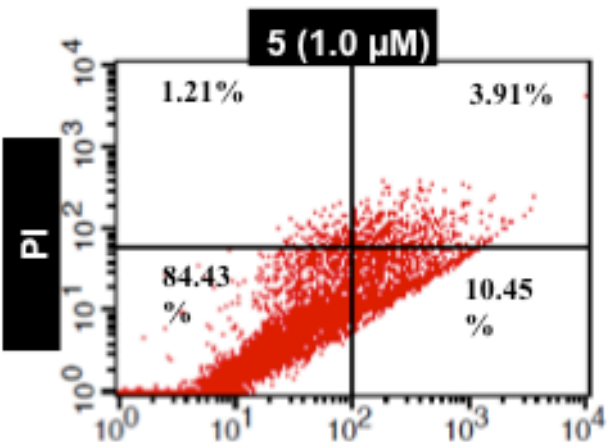

Annexin V - Alexa Fluor

(b)

Fig. 8 Assessment of apoptosis by annexin V alexa fluor 488 and propidium iodide (PI) dual staining in MDAMB-231 and HeLa cells populations (\%) after $24 \mathrm{~h}$ treatment (a) with $1.0 \mu \mathrm{M}$ concentration ( $\mathrm{IC}_{50}$ value) of compounds 1 and 3 for MDAMB-231 (b) with $0.6 \mu \mathrm{M}\left(<\mathrm{IC}_{50}\right.$ value), $0.8 \mu \mathrm{M}$ ( $\mathrm{IC}_{50}$ value) and $1.0 \mu \mathrm{M}$ (> $\mathrm{IC}_{50}$ value) concentrations of compound 5 for HeLa cells. The upper left quadrant shows necrotic cells (PI +ve/ annexin V -ve), upper right quadrant shows late apoptotic cells (PI +ve/ Annexin V +ve), lower left quadrant shows live cells (PI -ve/ Annexin V -ve) and lower right quadrant shows early apoptotic cells (PI - ve/ Annexin V +ve). Percentage of cells in four quadrants were calculated from three individual experiments. 


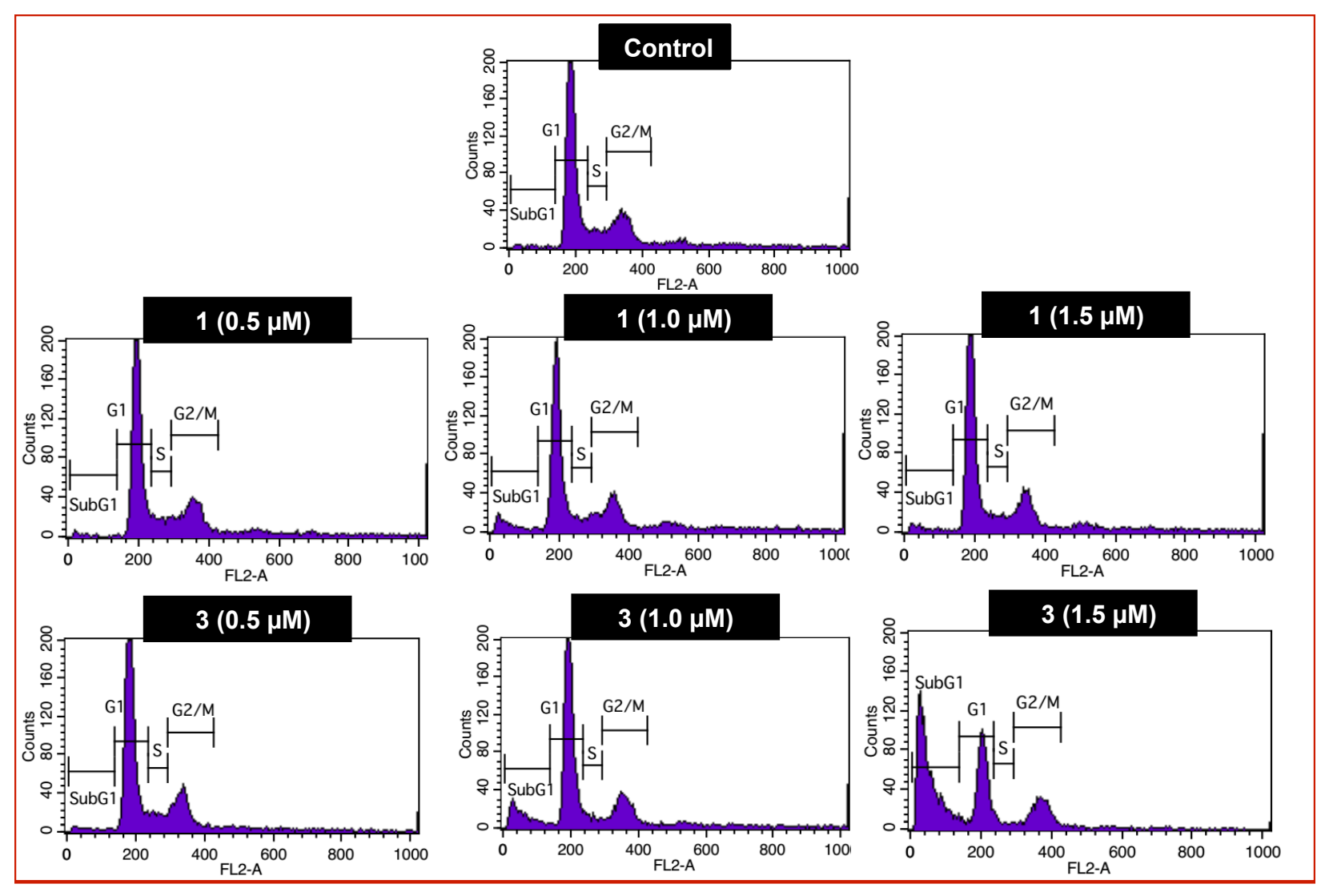

(a)

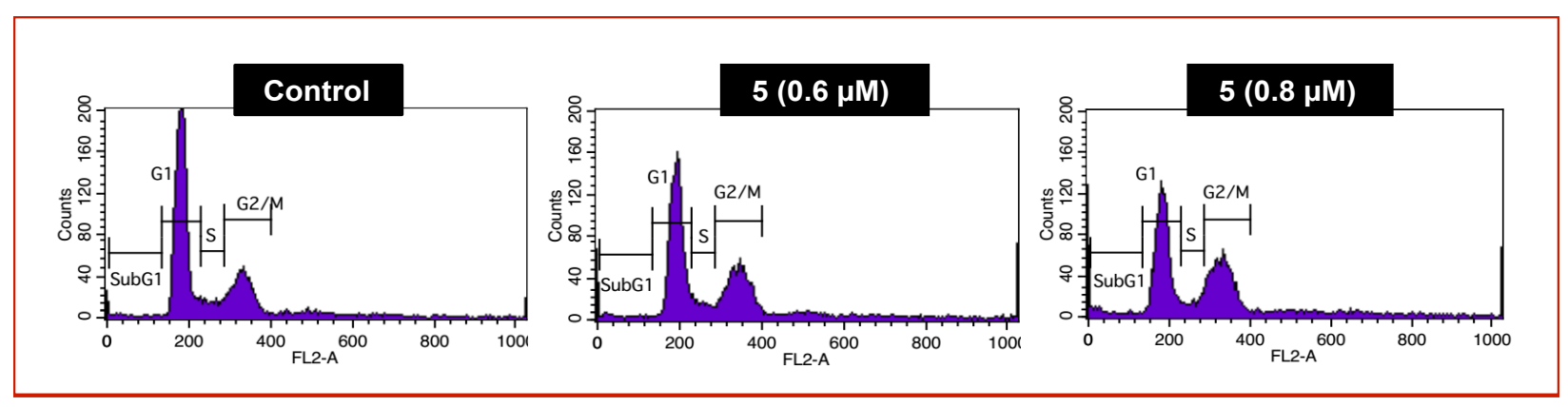

(b) 


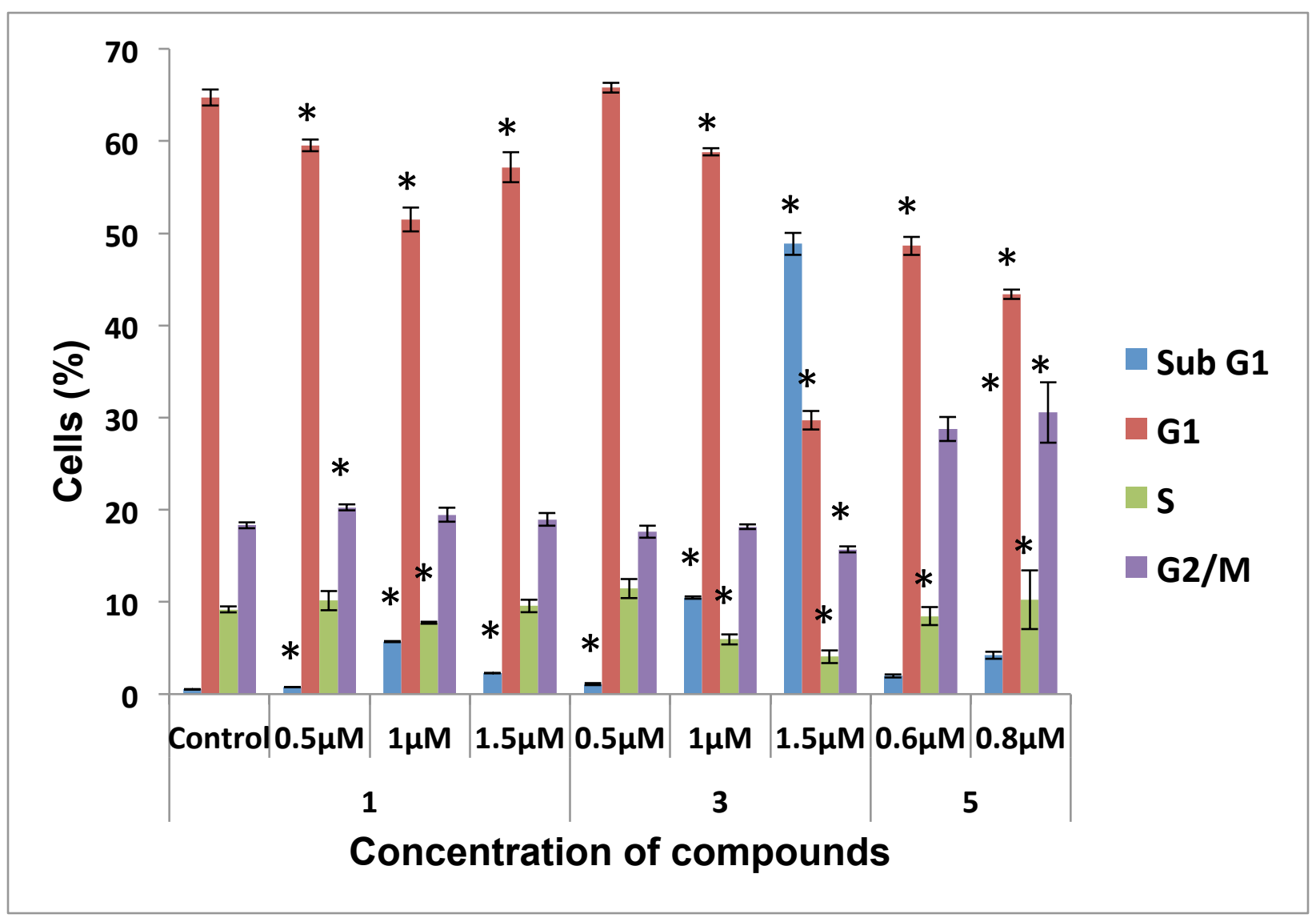

Fig. 9 Distributions of cell cycle phases studied through FACS analysis of PI stained (a) MDAMB-231 and (b) HeLa cells, after $24 \mathrm{~h}$ of exposure to concentrations of compounds 1, 3 and 5. The data indicated in the histogram refers to the percentage of cells in each phase of the cell cycle. Statistical analysis has been performed by one way ANOVA followed by Tukey test where $*$ denotes significant difference $(\mathrm{P}<0.05)$ as compared to control. 


\section{Table 1}

Crystal data and refinement details for pro-ligand $\mathrm{HL}^{4}$ and triphenyltin(IV) compounds $\mathbf{2}$ and $\mathbf{5}$

\begin{tabular}{|c|c|c|c|}
\hline Compound & $\mathrm{HL}^{4}$ & 2 & 5 \\
\hline Formula & $\mathrm{C}_{16} \mathrm{H}_{16} \mathrm{~N}_{2} \mathrm{O}_{2}$ & $\mathrm{C}_{33} \mathrm{H}_{29} \mathrm{~N}_{3} \mathrm{O}_{2} \mathrm{Sn}$ & $\mathrm{C}_{34} \mathrm{H}_{30} \mathrm{~N}_{2} \mathrm{O}_{2} \mathrm{Sn}$ \\
\hline Formula weight & 268.31 & 618.28 & 617.29 \\
\hline Crystal colour & yellow & orange-red & dark-orange \\
\hline Crystal size $/ \mathrm{mm}^{3}$ & $0.12 \times 0.16 \times 0.22$ & $0.12 \times 0.15 \times 0.24$ & $0.12 \times 0.24 \times 0.32$ \\
\hline Crystal system & monoclinic & monoclinic & monoclinic \\
\hline Space group & $I 2 / a$ & $P 2_{1} / c$ & $P 2_{1} / c$ \\
\hline$a / \AA$ & $15.3620(8)$ & 7.8101(3) & $10.4484(4)$ \\
\hline$b / \AA$ & $13.0274(5)$ & $19.1380(9)$ & $14.6258(6)$ \\
\hline$c / \AA$ & $14.4686(7)$ & $19.5298(8)$ & 19.6944(7) \\
\hline$\beta /^{\circ}$ & $105.179(6)$ & $97.547(4)$ & $100.490(3)$ \\
\hline$V / \AA^{3}$ & $2794.5(2)$ & $2893.8(2)$ & $2959.3(2)$ \\
\hline$Z$ & 8 & 4 & 4 \\
\hline$D_{\mathrm{c}} / \mathrm{g} \mathrm{cm}^{-3}$ & 1.275 & 1.419 & 1.385 \\
\hline$F(000)$ & 1136 & 1256 & 1256 \\
\hline$\mu(\mathrm{Mo} K \alpha) / \mathrm{mm}^{-1}$ & 0.085 & 0.917 & 0.895 \\
\hline Measured data & 5877 & 13908 & 12838 \\
\hline$\theta$ range $/^{\circ}$ & $3.1-26.5$ & $3.3-26.5$ & $3.0-26.5$ \\
\hline Unique data & 2883 & 5973 & 6102 \\
\hline Observed data $(I \geq 2.0 \sigma(I))$ & 1824 & 4784 & 4642 \\
\hline No. parameters & 186 & 354 & 354 \\
\hline$R$, obs. data; all data & $0.056 ; 0.092$ & $0.032 ; 0.047$ & $0.036 ; 0.056$ \\
\hline$a ; b$ in weighting scheme & $0.059 ; 1.198$ & $0.031 ; 0.366$ & $0.032 ; 0$ \\
\hline$R_{\mathrm{w}}$, obs. data; all data & $0.130 ; 0.155$ & $0.067 ; 0.073$ & $0.073 ; 0.081$ \\
\hline GoF & 1.03 & 1.03 & 1.06 \\
\hline \multicolumn{4}{|l|}{ Range of residual electron } \\
\hline density peaks $/ \mathrm{e} \AA^{-3}$ & $-0.19-0.24$ & $-0.26-0.30$ & $-0.32-0.44$ \\
\hline
\end{tabular}


Table 2

$\mathrm{IC}_{50}$ values $(\mu \mathrm{M})$ for free pro-ligands and triphenyltin(IV) compounds

1-6, $\mathrm{Ph}_{3} \mathrm{SnOH}$ and $\mathrm{CDDP}$ after $24 \mathrm{~h}$ exposure in cancer cell lines (MDAMB-231 and HeLa) and normal cells HEK 293

\begin{tabular}{|c|c|c|c|}
\hline \multirow[t]{2}{*}{ Test compounds } & \multicolumn{3}{|c|}{$\mathrm{IC}_{50}$ values $(\mu \mathrm{M}) \pm \mathrm{SE}^{\mathrm{a}}$} \\
\hline & MDAMB-231 cells & HeLa cells & HEK 293 cells \\
\hline $\mathrm{HL}^{1}$ & $>25$ & $>25$ & \\
\hline $\mathrm{HL}^{2}$ & $>25$ & $>25$ & \\
\hline $\mathrm{HL}^{3}$ & $>25$ & $>25$ & \\
\hline $\mathrm{HL}^{4}$ & $>25$ & $>25$ & \\
\hline $\mathrm{HL}^{5}$ & $>25$ & $>25$ & \\
\hline $\mathrm{HL}^{6}$ & $>25$ & $>25$ & \\
\hline $\mathrm{Ph}_{3} \mathrm{SnL}^{1}$ & $1.19 \pm 0.16$ & $2.23 \pm 0.08$ & $2.68 \pm 0.07$ \\
\hline $\mathrm{Ph}_{3} \mathrm{SnL}^{2}$ & $3.83 \pm 0.15$ & $2.5 \pm 0.19$ & $\mathrm{~b}$ \\
\hline $\mathrm{Ph}_{3} \mathrm{SnL}^{3}$ & $1.44 \pm 0.03$ & $1.78 \pm 0.12$ & $3.28 \pm 0.25$ \\
\hline $\mathrm{Ph}_{3} \mathrm{SnL}^{4}$ & $3.76 \pm 0.06$ & $6.18 \pm 0.03$ & $\mathrm{~b}$ \\
\hline $\mathrm{Ph}_{3} \mathrm{SnL}^{5}$ & $2.30 \pm 0.02$ & $0.88 \pm 0.0003$ & $3.91 \pm 0.08$ \\
\hline $\mathrm{Ph}_{3} \mathrm{SnL}^{6}$ & $2.45 \pm 0.02$ & $3.99 \pm 0.16$ & $\mathrm{~b}$ \\
\hline CDDP & $5.62 \pm 0.30$ & $23.63 \pm 0.20$ & $\mathrm{~b}$ \\
\hline $\mathrm{Ph}_{3} \mathrm{SnOH}$ & $>15$ & $>15$ & \\
\hline
\end{tabular}

${ }^{\mathrm{a}}$ Standard error.

${ }^{\mathrm{b}} \mathrm{ND}=$ Not done. 


\section{Legends to the figures}

Fig. 1 Generic structures with numbering protocol of pro-ligands $\mathrm{HL}^{\mathrm{n}}(\mathrm{n}=1-6)$ and tin phenyl moiety

Fig. 2 Perspective view of the molecular structure of $\mathrm{HL}^{4}$. Selected geometric parameters: $\mathrm{C} 7-\mathrm{O} 1$ 1.311(3), C7-O2 1.214(3), C8-N1 1.283(2) Å, O1-C7-O2 121.4(2), C2-N1-C8 123.31(18), N1-C8C9 $123.98(19)^{\circ}$. Intramolecular hydrogen bond: $\mathrm{O} 1-\mathrm{H} 1 \mathrm{o} \ldots \mathrm{N}=1.71(2) \AA, \mathrm{O} 1 \ldots \mathrm{N} 1=2.504(2) \AA$ with an angle of $157(3)^{\circ}$ subtended at $\mathrm{H} 1 \mathrm{o}$.

Fig. 3 Perspective view of the molecular structure of 2. Selected geometric parameters: Sn-O1 2.0705(18), C7-O1 1.307(3), C7-O2 1.234(3), N1-N2 1.254(3) A..

Fig. 4 Perspective view of the molecular structure of 5. Selected geometric parameters: Sn-O1 2.068(2), C7-O1 1.311(3), C7-O2 1.224(3), C8-N1 1.244(5) Å.

Fig. 5 Dose dependent cytotoxic effects of compounds 1-6 on (a) MDAMB-231 and (b) HeLa cells by MTT assay after incubation with various concentrations of compounds for $24 \mathrm{~h}$. Bars represent \pm SEM (n $=3$ ). Statistical analysis has been done by one way ANOVA followed by Tukey test where $*$ denotes significant difference $(\mathrm{P}<0.05)$ as compared to control.

Fig. 6 Dose-dependent generations of ROS when treated with $\mathrm{IC}_{50}$ concentrations of the respective compounds induced by (a) 1 and 3 in MDAMB-231 and (b) 5 in Hela cells detected by measuring the fluorescence intensity using DCFH-DA viewed through fluorescence microscope.

Fig. 7 Fluorescence microscope images showing morphological (nuclear) changes in MDAMB-231 and HeLa cells upon treatment with specified concentrations of compounds (1 and $\mathbf{3})$ and (5), respectively, by dual staining with Hoechst 33342 and PI for $24 \mathrm{~h}$. Yellow arrows represents live cell nuclei, white arrows show bright blue condensed apoptotic nuclei whereas red arrows show pink fragment apoptotic nuclei.

Fig. 8 Assessment of apoptosis by annexin V alexa fluor 488 and propidium iodide (PI) dual staining in MDAMB-231 and HeLa cells populations (\%) after $24 \mathrm{~h}$ treatment (a) with $1.0 \mu \mathrm{M}$ concentration $\left(\mathrm{IC}_{50}\right.$ value) of compounds 1 and 3 for MDAMB-231 (b) with $0.6 \mu \mathrm{M}$ ( $<\mathrm{IC}_{50}$ value), $0.8 \mu \mathrm{M}$ ( $\mathrm{IC}_{50}$ value) and $1.0 \mu \mathrm{M}\left(>\mathrm{IC}_{50}\right.$ value) concentrations of compound $\mathbf{5}$ for HeLa cells. The upper left quadrant shows 
necrotic cells (PI +ve/ annexin V -ve), upper right quadrant shows late apoptotic cells (PI +ve/ Annexin V $+\mathrm{ve}$ ), lower left quadrant shows live cells (PI -ve/ Annexin V -ve) and lower right quadrant shows early apoptotic cells $(\mathrm{PI}-\mathrm{ve} /$ Annexin V +ve). Percentage of cells in four quadrants were calculated from three individual experiments.

Fig. 9 Distributions of cell cycle phases studied through FACS analysis of PI stained (a) MDAMB-231 and (b) HeLa cells, after $24 \mathrm{~h}$ of exposure to concentrations of compounds 1, 3 and $\mathbf{5}$. The data indicated in the histogram refers to the percentage of cells in each phase of the cell cycle. Statistical analysis has been performed by one way ANOVA followed by Tukey test where $*$ denotes significant difference $(\mathrm{P}$ $<0.05)$ as compared to control. 